Est Ag 51 (2016) 449-520

\title{
Jesús de Nazaret y el evangelio de la misericordia
}

\author{
Luis Ángel Montes Peral
}

REsumen: El Evangelio de la Misericordia ocupa el centro mismo de las intenciones más íntimas de Jesús. Durante su andadura terrena toda su persona, vida y obra consistieron en hacer visible al Padre bueno de los cielos y obrar en su nombre de la manera como el Altísimo desea hacerlo con los hombres. Con sus palabras, hechos y gestos, y de un modo muy especial con su Muerte y Resurrección, mostró en la práctica el infinito amor divino, sobre todo a favor de los pobres, enfermos y pecadores. Conocer el modo concreto cómo el Profeta de Nazaret realizó esta misión de mostrar el auténtico rostro de Dios en la existencia humana, nos lleva a los creyentes a obrar y a amar como el Maestro nos lo testimonió: acogiendo sin reservas a los necesitados del tipo que sean, mostrándoles clemencia y piedad, compasión y perdón y apostando por la fraternidad en un mundo egoísta y violento, necesitado de un paradigma nuevo.

AbSTRACT: The Gospel of Mercy is at the very centre of Jesus' most intimate intentions. During his time on earth, his whole person, life and work lay in making manifest the goodness of his Heavenly Father and doing works in His name in the way that the Almighty wishes. With his words, deeds and gestures, and especially with his Death and Resurrection, he showed infinite divine love in practice, particularly for the poor, the sick and sinners. Recognising the particular way in which the Prophet of Nazareth carried out this mission of showing God's true face in human existence leads us as believers to work and love in the way that the Master bore witness: unreservedly welcoming anyone with whatever need they may have, showing them clemency and mercy, compassion and forgiveness, and opting for fraternity in a selfish, violent world that is in need of a new paradigm. 


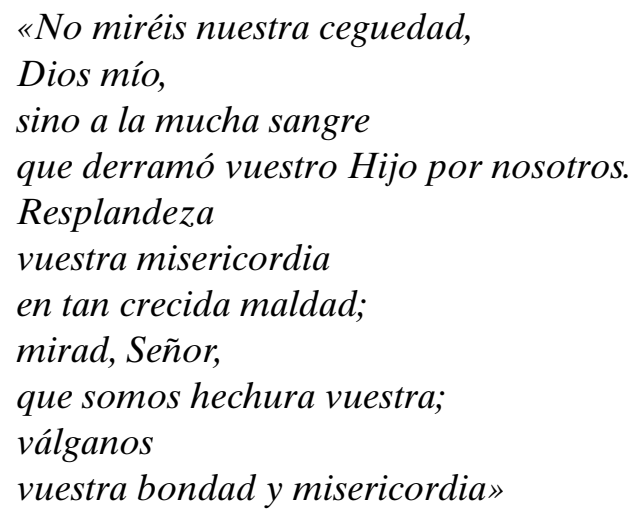

(Santa Teresa de Jesús, Exclamación 8).

En nuestra vida espiritual estamos tan identificados con Cristo, aunque en no pocas ocasiones sea sólo de una manera teórica, que lo que conmueve a Jesucristo, también nos conmueve a nosotros. De ahí la importancia de conocer su misericordia, icono del cariño entrañable del Padre, ya que construye de una manera sobresaliente nuestro acercamiento progresivo a esa gran virtud, que tanto necesita la sociedad actual y también nuestra vida, amenazada por el egoísmo y la cerrazón existencial. Contemplar de verdad la misericordia de Jesús, no sólo pone nuestra existencia en juego, también nos ayuda a salir más de nosotros mismos, para hacernos cargo del dolor y de la miseria en relación con los demás, que nos interrogan e invitan a la conversión ${ }^{1}$.

\footnotetext{
${ }^{1}$ El texto que sigue tiene como base una ponencia, presentada en Palencia, en el marco de una Jornada de Teología, titulada «La misericordia en su luz», el día 22 de febrero de 2016, lunes de la Segunda Semana de Cuaresma.
} 


\section{Introducción:}

La historia de Jesús constituye la irrupción en Israel de una gran alegría con repercusiones universales (Lc 2,10). Se anuncia un mensaje tan sencillo como revolucionario: aparece un Niño en un pesebre, que trae la vida a todos los hombres. Él es el Salvador, el Mesías, el Señor (Lc 2,11), en quien se muestra como en ninguna otra persona la misericordia de Dios. Ese Niño se hará adolescente y en el Templo de Jerusalén proclamará el distanciamiento de su madre biológica, para centrar su existencia expropiada en el Padre del cielo (Lc 2,49). Entregará su vida en las manos de ese Padre bueno, entendido y experimentado como Abba querido. Precisamente en el descubrimiento de su $A b b a$ con palabras, obras y signos liberará a los hombres de su egoísmo y les abrirá al Dios del amor, en quien se encuentra la fuente de la salvación.

Por testimoniar con todas las consecuencias una imagen nueva de Dios, que da paso al mismo tiempo a una visión renovada de la persona humana, acaba su corta vida en la cruz. En esas nuevas imágenes de Dios y de la persona humana se subvierte la realidad existente en la sociedad de su tiempo y se hacen trizas los lenguajes existentes hasta entonces: en virtud de la muerte del Crucificado irrumpe la revelación definitiva del Dios del amor y se lleva a efecto la sanación del género humano, herido de disolución a lo largo de los tiempos.

En la poquedad humana de Jesús se transparenta la inmensidad de Dios, puesta al servicio de los dolientes de la tierra y en beneficio de la felicidad humana, que no se consigue por la violencia y el poder sino a través de la misericordia y el servicio. Aquí radica la revolución propiciada por personaje tan singular, que es el mayor don divino dado por el Padre a los hombres (Jn 3,16).

He titulado esta reflexión «JESÚS DE NAZARET Y EL EVANGELIO DE LA MISERICORDIA». Y lo hago con toda determinación, por el valor que tiene la humanidad del Hijo de Dios, sobre todo en el tema de la misericordia. Al hablar de Jesús de Nazaret me estoy refiriendo al Jesús terreno, que fue un judío de cuerpo y alma. Por eso al comenzar la exposición tengo que dejar bien claro que, en relación con la vivencia y anuncio de la misericordia divina, Jesús se muestra en su andadura histórica como totalmente judío, hebreo por los cuatro costados. 


\title{
Jesús y la tradición bíblica sobre la misericordia
}

Mucho de lo que Jesús expone sobre la gracia de la misericordia se encuentra en la mejor tradición bíblica, la testimoniada por profetas y sacerdotes, sabios y justos del Primer Testamento, que tanto hicieron por propagar la religión yahvista y mostrar sus fundamentos en torno al amor. No se puede conocer en profundidad lo que Jesús enseña sobre ella, si se desconoce lo transmitido por la Escritura Santa, que presenta la misericordia como el primer y más generoso atributo divino en su relación con los hombres y habla con frecuencia de que la misericordia de Dios es eterna y encuentra cabida en todas las situaciones de los israelitas.

Pongamos algunos ejemplos: Encontramos una de las mejores definiciones bíblicas de Dios, en la que prima la misericordia, en este famoso texto de la historia de Moisés, que no me resisto a transcribir:

\author{
«El Señor bajó de la nube y se quedó allí con él \\ y Moisés pronunció el nombre del Señor. \\ El Señor pasó ante él proclamando: \\ "Señor, Señor, Dios compasivo y misericordioso, \\ lento a la ira y rico en clemencia y lealtad, \\ que mantiene la clemencia hasta la milésima generación, \\ que perdona la culpa, el delito y el pecado, \\ pero no los deja impunes \\ y castiga la culpa de los padres en los hijos y nietos, \\ hasta la tercera y cuarta generación”»(Ex 34,5-7).
}

Joel, uno de los doce profetas, el segundo en la lista del Canon de Libros Sagrados, aunque escribió en época tardía, tiene en su corta profecía una magnífica presentación de conversión al Dios vivo, que es Señor de la misericordia:

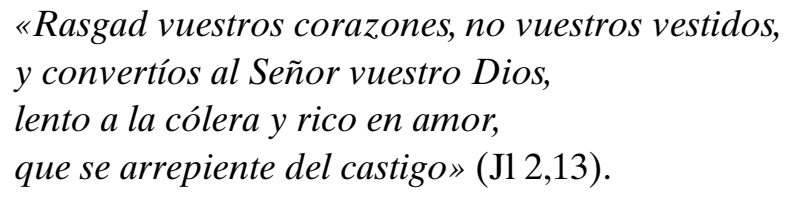

Bellísimo es el pasaje de uno de los más antiguos profetas escritores. Adentrados en la época asiria, al final de su profecía tal como hoy se con- 
serva, invita a los suyos a volver el corazón al Dios de la misericordia y el perdón:

"¿Qué Dios hay como tú, capaz de perdonar el pecado, de pasar por alto la falta del resto de la heredad?

No conserva para siempre su cólera, pues le gusta la misericordia.

Volverá a compadecerse de nosotros, destrozará nuestras culpas,

arrojará nuestros pecados a lo hondo del mar.

Concederás a Jacob tu fidelidad

y a Abrahán tu bondad, como antaño prometiste a nuestros padres» (Miq 7,18-20).

El Deuteroisaías, por su parte, en las postrimerías de la cautividad de Babilonia, se ha adentrado como nadie, con su admirable genialidad poética, en la entraña misma de Dios, que es Padre y Madre a la vez:

"¿Puede una madre olvidar al niño que amamanta, no tener compasión del hijo de sus entrañas?

Pues, aunque ella se olvidara, yo no me olvidaré» (Is 49,15).

Son muy numerosos los salmos, que ensalzan con gozo la misericordia divina. Reflexionemos algunos versículos:

«Recuerda, Señor, que tu ternura

y tu misericordia son eternas;...

acuérdate de mí con misericordia,

por tu bondad, Señor.

El Señor es bueno y es recto

y enseña el camino a los pecadores» (Sal 25,6-8).

"Alegra el alma de tu siervo,

pues levanto mi alma hacia ti, Señor,

porque tú, Señor, eres bueno y clemente,

rico en misericordia con los que te invocan» (Sal 86,4).

«Levántate y ten misericordia de Sión,

que ya es hora y tiempo de misericordia»(Sal 102,14). 
Los primeros siete versículos del Salmo 116 describen de forma bien sincera, muy interiorizada, lo que en realidad significa la misericordia en el aquí y ahora para el piadoso en una situación límite, vuelto hacia Dios, consciente de su gracia y confiado en sus manos poderosas, cuando la tristeza le invadía y se encontraba a las puertas de la muerte:

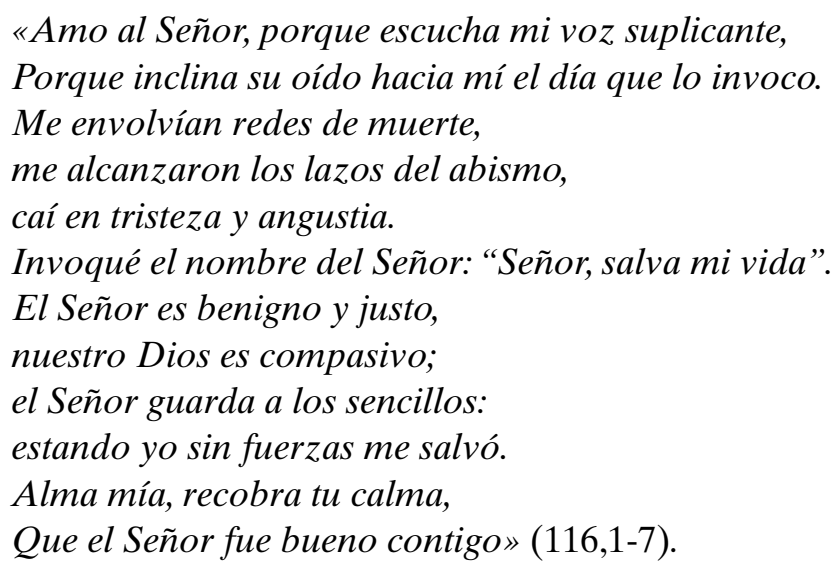

El Salmo 145 alaba la grandeza de la bondad divina en un largo acróstico, en el que se resalta su ternura con todas las criaturas y de una manera muy especial con los pobres; sostiene a los que están a punto de caerse y endereza a los que se doblan. Entre otras cosas constata:

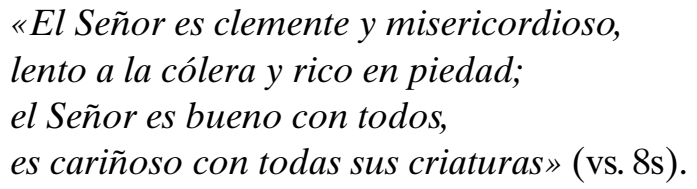

El jubiloso salmista percibe cómo Dios actúa salvadoramente en su existencia cotidiana y empieza y concluye su sentida acción de gracias con un recuerdo imborrable de su misericordia:

«Dad gracias al Señor porque es bueno, porque es eterna su misericordia» (Sal 118,1.29).

El 103 constituye una bellísima oración a Dios Padre que ama y perdona, que no quiere la muerte del pecador, sino que cambie de proceder y viva. 
«Como un padre siente ternura por sus hijos, siente el Señor ternura por los que le temen». «Pero la misericordia del Señor dura desde siempre y por siempre, para aquellos que le temen; su justicia pasa de hijos a nietos» (Sal 103,13.17).

Podíamos multiplicar los ejemplos. Baste ya como colofón conclusivo la experiencia de este salmista, que pasa de las tinieblas a la luz, anclado como está en el Dios bueno de la salvación del que va adquiriendo creciente experiencia:
«Porque yo confío en tu misericordia, mi alma gozará con tu salvación, y cantaré al Señor por el bien que me ha hecho» $($ Sal 13,6).

En la literatura sapiencial aprende el sabio piadoso de la misericordia divina a rechazar la venganza y ejercitar el perdón:
«El vengativo sufrirá la venganza del Señor, que llevará cuenta exacta de sus pecados.
Perdona la ofensa a tu prójimo
$y$, cuando reces, tus pecados te serán perdonados.
Si un ser humano alimenta la ira contra otro, ¿cómo puede esperar la curación del Señor?
Si no se compadeces de tus semejantes ¿cómo pide perdón por sus propios pecados? (Eclo 28,1-4).

Por último, en la época griega, en tiempos de la persecución de Antíoco IV Epifanes, un valiente joven judío de nombre Azarías ora a Dios en estos términos íntimos: «trátanos según tu clemencia y abundante misericordia, líbranos con tu obrar admirable y da gracia a tu nombre, Señor» (Dan $3,43)$.

En definitiva, los relatos de las numerosas tradiciones bíblicas, la buena noticia anunciada por los profetas, las reflexiones de los sabios y las oraciones de los salmistas y piadosos, todos ellos participan del firme convencimiento de que Dios es bueno y su bondad alcanza hasta límites insospechados: perdona los pecados, tiene compasión de los tambaleantes y muestra una misericordia sin límites. 
No cabe duda que Jesús, entrañado en la hondura de la religiosidad de su pueblo, conoció bien todos los textos presentados aquí, los meditó largamente y bebió de ellos en la conformación de su espiritualidad sobre la misericordia entrañable de su Padre, participando de las mismas convicciones de profetas, sabios, poetas y piadosos sobre el amor divino.

Pero en el tratamiento del contenido sobre la misericordia también entra un componente, que eleva al profeta de Nazaret por encima del judaísmo de su tiempo e incluso sobrepasa con creces las enseñanzas bíblicas anteriores. Ese componente se identifica sobre todo con su persona misma, ya que su vida y obra, sus palabras, acciones y gestos obran siempre en nombre y en lugar de Dios. Ni los profetas de la época bíblica, ni los sabios de otro tiempo, ni los justos por piadosos que fueran, se habían atrevido a mostrar semejante autoridad, porque carecían de ella.

Y es que el Jesús terreno exhibió una pretensión, que lo sitúa a la altura de Dios, siempre en comunión amorosa con el Padre de los cielos. La misericordia que él muestra constituye la plasmación perfecta de la querida por el Padre, es la misma en contenido e intensidad. Sus prerrogativas, bien miradas, son divinas en su origen y dan un vuelco a la historia humana:

$$
\begin{aligned}
& \text { «Bienaventurados los ojos que ven lo que vosotros veis! } \\
& \text { Porque os digo que muchos profetas y reyes } \\
& \text { quisieron ver lo que vosotros veis, y no lo vieron; } \\
& \text { y oír lo que vosotros oís, y no lo oyeron» (Lc 10,23; Mt 13,16s). }
\end{aligned}
$$

Dichosos entre otras cosas, sí, debido el mensaje y el comportamiento de Jesús sobre lo que el amor misericordioso divino significa para los humanos como componente decisivo en la transformación interior de las personas. Bienaventurados los que pudieron escuchar sus bienaventuranzas, sobre todo la que tiene que ver con la misericordia.

Conviene adelantar también aquí, que existe otra diferencia bien significativa en el empleo de la misericordia conforme a la tradición bíblica y en el comportamiento de Jesús que testifica la tradición evangélica: Mientras «la Biblia entiende la misericordia, no a partir de los sentimientos, sino a partir de la fidelidad de Dios a la alianza» (H. -H. Esser) en Jesús los sentimientos juegan una capital relevancia en la expresión fundante de la misericordia, que no cabe duda está en perfecta conformidad con la fidelidad divina.

Jesús irrumpe con su misericordia en la realidad tenebrosa de la miseria humana de su tiempo y transforma a las personas con su acción salvadora 
y su atracción liberadora. Como tendremos ocasión de comprobar ahora, en la puesta en práctica de la misericordia Jesús tiene la fiel actitud de obediencia al Padre, los ojos bien abiertos para contemplar la realidad tal como es y una fina sensibilidad para mostrar empatía con las necesidades ajenas, ayudando a pobres, pecadores y enfermos en todo aquello que estaba al alcance de sus posibilidades y fuerzas.

En conformidad con el Maestro, llevar a los hombres, quienes quieran que sean, la acogida y misericordia de Jesús, que reconforta, consuela y anima a los que buscan ayuda y piden refugio de cualquier tipo constituye en la hora actual la tarea permanente de sus seguidores. De ahí lo mucho que importa conocer cómo se comportó Jesús.

\section{Todo empezó en Galilea (Hch 10,37)}

Jesús empezó su actividad pública, anunciando el Evangelio del Reino en la Galilea, la región norte de Palestina, en la que tanto tiempo había vivido y conformado su rica espiritualidad. Desde los comienzos, cuando tenía aproximadamente treinta años (Lc 3,23), llevó una existencia itinerante, pero nunca actuó solo, como si fuera un Maestro solitario. Primero fue acompañado de dos parejas de hermanos, pescadores galileos: Pedro y Andrés, Santiago y Juan, que le siguieron incondicionalmente, después de dejar su familia, su trabajo y sus bienes (Mc 1,16-20 par.).

Más tarde se unieron al pequeño grupo ocho hombres más, el llamado colegio de los Doce Apóstoles (Mc 3,13-19par.). Por último fueron detrás también otros discípulos, tanto hombres como mujeres (Lc 8,1s; Mc 15,40s), formando así un buen conjunto de personas, cuyo número no podemos precisar. Escucharon el mensaje y luego nos lo transmitieron, recordando su intencionalidad y mostrando lo más enjundioso de su rico contenido. ¡Con su amor lograron cambiar el mundo! La síntesis de todas las enseñanzas del Nazareno se concentra en una palabra: misericordia. «Todo en Jesús habla de misericordia, es más, Él mismo es la misericordia» (Papa Francisco, Mensaje para la XXXI Jornada Mundial de la Juventud 2016, 2).

\subsection{El contenido central del evangelio de la misericordia}

El núcleo de su mensaje podíamos formularlo así: « iLlega a nuestras vidas, necesitadas de alegría, liberación y esperanza, el Padre de los cielos, el 
Soberano del universo, con la inmensidad de su amor! iQuiere proclamar una amnistía general: perdona nuestros pecados y desea concedernos un corazón nuevo de hijos y hermanos! Además nos invita a acoger prestos este amor, cargado de benignidad y misericordia, y a obrar en consecuencia».

Jesús siente la necesidad interior de anunciar el amor misericordioso del Padre, que desea reinar en el mundo mediante el ejercicio de una relación entrañable, que se abre primero a los judíos y que en su momento llegará al resto de los hombres. El destino de ese amor ofrece, por lo tanto, características universales, la humanidad entera está implicada en la predilección divina por los humanos. Nadie puede sentirse excluido del corazón misericordioso del Señor de la tierra y de los cielos. El Soberano del mundo nos ha amado y nos sigue amando a todos, como una fuente inagotable de incondicional entrega a los que estamos llamados a ser sus hijos.

El Maestro de Nazaret nos trae así el Evangelio con mayúscula, es decir, la Buena Noticia por excelencia, que puede transformar por completo la existencia de cada día. Y en el centro mismo de este Evangelio, de esta Buena Noticia se alza la misericordia entrañable del Padre, la ternura con que trata a los hombres, la dedicación con que se pone a su servicio y quiere sacarlos de su postración. La misericordia impregna por completo la experiencia vital de Jesús. No podría entenderse su actuación pública, realizada en nombre y en lugar del Padre, sin la acogida de los pecadores, sin el perdón de las culpas, sin la conmiseración ante todas las formas del mal y sin la predilección por los débiles².

La llegada del Padre con la convincente fuerza de su amor, mediante el anuncio del Evangelio de la Misericordia por parte de Jesús, supone un giro radical en la historia de la humanidad. Lo negativo da paso a lo positivo. La violencia sin sentido queda a un lado ante la oferta de la salvación. Al pecado le sustituye la gracia y al odio la acogida incondicional de la filiación y la fraternidad. La puesta en práctica, afectiva y efectiva, de la mi-

\footnotetext{
2 «En realidad, la misericordia constituye el núcleo central del mensaje evangélico, es el nombre mismo de Dios, el rostro con que se reveló en la Alianza Antigua y plenamente en Jesucristo, encarnación del Amor creador y redentor. Este amor de misericordia ilumina el rostro de la Iglesia y se manifiesta en los sacramentos, especialmente el de la Reconciliación, y mediante las obras de caridad, comunitarias e individuales. Todo lo que la Iglesia dice y realiza, manifiesta la misericordia que Dios tiene para el hombre. Cuando la Iglesia debe recordar una verdad olvidada, o un bien traicionado, lo hace impulsada por el amor misericordioso, para que los hombres tengan vida y la tengan en abundancia (Jn 10,10). De la misericordia divina, que pacifica los corazones, brota además la auténtica paz del mundo, la paz entre los diversos pueblos, culturas y religiones» (Benedicto XVI, Homilía del domingo de la Misericordia Divina, 30 de marzo de 2008).
} 
sericordia constituye un signo seguro, fehaciente de que ha irrumpido y avanza el reinado de Dios.

El hombre está llamado a la vida, de modo que la vida y la misericordia van de la mano, incluso se enlazan, cuando el Reino es proclamado. La misericordia divina obra como elemento transformador, que configura y sana los comportamientos humanos. Porque está impregnada de amor, la misericordia, por la que Jesús apuesta, permanece como patrimonio de una humanidad renovada, liberada de las fuerzas del mal, que destruyen lo más íntimo de su identidad.

Para recibir debidamente este mensaje, el Nazareno requiere de sus oyentes la conversión, el cambio de actitudes y valores, ya que están llamados a ser y obrar como hijos y como hermanos. La exposición perfecta de este mensaje encuentra su contenido central en la oración del Señor: en el Padre-nuestro, que constituye un resumen perfecto de toda la vida del discípulo. Por eso este anuncio de Jesús se alzará más tarde como el principio absoluto del cristianismo y donde radica la capacidad de una religión para la sinceridad y la convicción, para la acogida y el aliento.

Desde que Jesús nos mostró al Padre misericordioso, la realidad interior y exterior del ser humano se transforman por completo, ya nada puede ser como antes. Desde ese momento conocemos de verdad, quién es Dios para nosotros: un Padre bueno, que nos quiere, llamándonos por nuestro nombre, que se apena si rechazamos su ofrecimiento y que sufre lo indecible, si nos perdemos por no tomar en serio la oferta de misericordia y verdad que nos brinda con una generosidad completamente desinteresada.

\subsection{Filiación y fraternidad}

Abrir el corazón al Padre y a los hermanos representa lo mejor que puede pasar en la vida humana. Por eso el Evangelio del Reino conlleva dos realidades entusiasmantes: la divinización y la humanización. ¡Somos verdaderos hijos de Dios y el Espíritu nos capacita para conformar nuestra existencia entera como tales! Al mismo tiempo, jsomos hermanos de nuestros semejantes y podemos comportarnos como tales! Jesús nos invita a vivir en comunión íntima con el Padre y con los hermanos, ya que aquí radica lo esencial del ser cristiano.

Esa doble relación tiene como base el amor benevolente, complaciente y condescendiente, la misericordia y el cariño del Padre Bueno de los cielos, cargado de compasión con los que sufren. Desde ese fundamento 
todo se construye y todo fructifica. Sin esta base los mayores esfuerzos pueden quedar totalmente baldíos por falta de fundamento firme.

Pero hay algo más que conviene atender debidamente: en lo más nuclear del Reino los pobres son objeto de un afecto especial del Padre, en realidad, «son los privilegiados de la misericordia divina» (MV 15), los receptores principales de los frutos más granados del Evangelio de la Misericordia. Conforme el mensaje de Isaías, el Mesías se dirige sobre todo a los pobres, que son evangelizados, a los cautivos, a quienes se les proclama la libertad, a los ciegos, que se les da la vista, proclamando para ellos la gracia y la clemencia del Padre (Is 61,1s; Lc 4,18-21).

Entendiendo el mensaje del Reino así, de acuerdo con la intención última de Jesús, podemos sacar algunas conclusiones.

\subsection{Consecuencias}

1.3.1. No puede confundirse la misericordia con la debilidad espiritual o con una visión peyorativa, dulzona, hasta melodramática de la fe práctica. Bien al contrario, ocupa el centro mismo de la reflexión y acción teológicas. Como ha constatado con razón el cardenal Walter KASPER, en su famoso libro Barmherzigkeit, la misericordia alcanza la esencia misma del Evangelio, se legitima como un concepto fundamental en la entraña misma del cristianismo. No hay religión verdadera sin misericordia y ternura, porque el Padre de Jesús es eso precisamente: misericordia y ternura. Una misericordia y ternura, que deja intacta, incluso eleva la dignidad tanto por parte del que la practica, como del que la recibe.

1.3.2. La misericordia no relativiza el pecado. Bien al contrario, porque sabe lo mucho que daña al hombre, se presenta en su expresión de encuentro con el otro como la manera concreta de regenerar al ser humano, encadenado al mal de todo tipo y de un modo especial al pecado, que supone una negación de Dios, de uno mismo, de los otros hombres y de la creación. Recordando a San Pablo podemos decir que donde abundó el pecado, sobreabundó la gracia. Al pecado humano el Padre respondió de la única manera posible para poder regenerar al pecador: derrochando amor. 
1.3.3. La misericordia no se contrapone a la justicia, pero va más allá de ella. Actuando misericordiosamente el Padre no obra contra la justicia en ninguna de sus formas, sino que la supera y sobrepasa, volcándose en el bien de los humanos con la generosidad del amor. Sin la misericordia del Reino, la estricta implantación de la justicia podía volverse cruel para los débiles y vacía de sentimientos para los descarriados. Un Padre exclusivamente justo, acabaría condenando de forma implacable a los pecadores y a la larga a la totalidad de los hombres, ya que todos participamos de la condición pecadora en mayor o menor medida.

1.3.4. «En la Biblia, muchas veces se hace referencia a la justicia divina y a Dios como juez. Generalmente es entendida como observación integral de la ley y como el comportamiento de todo buen israelita conforme a los mandamientos dados por Dios. Esta visión, sin embargo, ha conducido no pocas veces a caer en el legalismo, falsificando su sentido originario y oscureciendo el profundo valor que la justicia tiene. Para superar la perspectiva legalista, sería necesario recordar que en la Sagrada Escritura la justicia es concebida esencialmente como un abandonarse confiado en la voluntad de Dios» (MV 20). Un Dios bueno, que se deleita en ser generoso con los hombres, y practicar con ellos la acogida incondicional. De este modo lo ha mostrado Jesucristo en su relación con los fariseos y maestros de la ley. «Éstos, por ser fieles a la ley, ponían solo pesos sobre las espaldas de las personas, pero así frustraban la misericordia del Padre. El reclamo a observar la ley no puede obstaculizar la atención de las necesidades que tocan la dignidad de las personas» (MV 20).

1.3.5. La misericordia tampoco se verifica en contra de ningún principio ético, ya que tiene una base real y efectiva, que fructifica cuando se pone en práctica y logra su objetivo. No hay amor, que llegado el caso, no se vuelva misericordia y se exprese a través de ella. El infinito amor de Dios ofrece en expresión suma estas características y se mueve entre la clemencia y la piedad, la compasión y el perdón. La sociedad y sus valores irían mucho mejor de lo que van, si se practicaran las obras de misericordia, en la forma y medida que encuentran sentido afectivo y efectivo. Veríamos entonces que el principio de la misericordia logra eficacia concreta, porque los resortes del amor funcionan en el corazón humano. 
1.3.6. Acoger el Evangelio de la Misericordia lleva consigo un mensaje liberador: implica aceptar con gozo el principio misericordia y contemplar a los marginados del tipo que sea, no como culpables, dignos de ser rechazados, sino como hermanos, a quien hay que acoger; de modo que la misericordia sea la mirada de afecto y ternura, como es la del Padre, y quiere que sea también la nuestra en la relación con los que están llamados a relacionarse con nosotros hermanos. La misericordia busca la solidaridad y nos ayuda a recuperar el sentido de humanidad, como respuesta en positivo a la realidad humana. La misericordia no se compagina con el egoísmo y mucho menos con el odio del tipo que sea, ya que está guiada por el perdón y la compasión en sus formas más auténticas y efectivas.

1.3.7. La misericordia contrapone su modo de actuar a la violencia, la crueldad y la venganza en todas sus formas. Se identifica con la comprensión del dolor de las personas concretas, tratando de extirparlo en la medida que resulta posible y factible. Ejercita el perdón incondicional y practica la compasión con la benevolencia propia del que le interesa en lo más íntimo la necesidad del prójimo. Tiene mucho de empatía, humanidad, solidaridad y filantropía en el sentido más genuino de estos términos. La misericordia puede transformarlo todo, también la propia vida, como ha afirmado con frecuencia el Papa Francisco desde los inicios de su pontificado.

1.3.8. Resumiendo: En la historia de Jesús la misericordia admite tres sujetos bien relacionados entre sí: en primer lugar Dios, el Padre, principio de toda misericordia. En segundo lugar el mismo Jesús, que refleja, realiza y testimonia de diversas formas la misericordia del Padre. En tercer lugar el hombre, el discípulo, llamado a seguir al Maestro por el camino de la misericordia. Como acción primaria en beneficio del prójimo ocupa un lugar de privilegio en la puesta en práctica de los preceptos de la ley, hasta el punto que el juicio final se decidirá conforme al cumplimiento o no de las obras de misericordia (Mt 25,31ss).

Si las cosas son así, resulta muy importante, para ahondar en la múltiple realidad de la misericordia, que ofrece un buen número de rasgos identificadores, contemplar el comportamiento de Jesús, que obra en lugar y en nombre del Padre durante su existencia terrena y su modo de posicionarse 
en la sociedad de su tiempo. Nos detendremos de un modo especial en los acontecimientos de su muerte y resurrección por la significación decisiva en su ser y quehacer en este mundo. Observados los evangelios, la vida y obra del profeta de Nazaret ofrecen remarcadas características, que nos ayudan a conocer bien, qué comporta en lo concreto la misericordia en la revelación del rostro bondadoso de Dios y cómo la vivió y testimonió en su quehacer de cada día.

\section{LO QUE ES EL PADRE PARA MÍ, CONTEMPLANDO A JESÚS MISERICORDIOSO, ESTOY LLAMADO YO A SERLO PARA LOS DEMÁS}

\section{Modo concreto de cómo Jesús anunció y testimonió el evangelio de la mi- sericordia}

Antes de nada vayan por delante estas consideraciones metodológicas: Puesta nuestra mirada en el Señor, necesitamos mucho entender y conformar un corazón bien dispuesto, para luego obrar en consecuencia, siguiendo las directrices que nacen del Evangelio de la Misericordia, traído por Jesús. Lo que importa sobre todo es la acción misericordiosa, pero sin entender debidamente cómo se llega a ella y cómo la puso por obra Jesús en su propósito de hacer realidad operante la llegada del reinado de Dios, puede ser errática y hasta perjudicial la acción. Entender como discípulos nos ayuda, por lo tanto, a saber vivir y actuar conforme los patrones trazados por el profeta de Nazaret.

No podemos determinar con exactitud, si hubo un progreso ascendente en la exposición de las enseñanzas de Jesús en torno a la misericordia. Y cómo se desarrolló esa evolución en el transcurso de su andadura histórica. Carecemos de datos exactos para establecerlo. Una cosa aparece bien clara: en su actuación pública la misericordia no se redujo a una idea sublime, que prestigió su predicación, más bien conformó todo un entramado de actitudes, hechos, comportamientos, señales, que llegaron a las personas de carne y hueso en la vida diaria y las transformaron en la medida que les ayudaron a reparar su humanidad herida.

Tal como ahora aparece en los evangelios, la exposición de la enseñanza sobre la misericordia comprende toda su actuación pública, empezando por la Baja Galilea hasta concluir en Jerusalén, ciudad en la que se multiplicaron los signos de misericordia, muchos de los cuales no tuvieron 
respuesta positiva por parte de sus destinatarios. La expansión de sentimientos de acogida y la expresión de una espiritualidad de las emociones de misericordia enmarcan de manera bien clara toda la etapa jerosolimitana.

Allí su vida se volvió más intensa y su intención salvadora más decidida, incluso más provocadora. Hay un secreto y un misterio en sus palabras y hechos de entonces, que sólo puede desvelarse, cuando se tiene en cuenta la realidad del seguimiento entre sus discípulos. Ir detrás de Jesús significa tanto como estar en la mejor disposición para comprender la anchura y largura de la misericordia divina en la actuación del Maestro Nazareno e imitarla en la propia vida.

De forma general podemos afirmar que Jesús quiso mostrar esa misericordia del Padre anunciando con intensas palabras su inmenso amor, sanando a enfermos de todo tipo con su autoridad y perdonando a los pecadores en nombre de su Abba querido. Pero también curó las heridas de la culpa y del egoísmo, superó el rencor y la venganza, que envenena peligrosamente las vidas y las buenas relaciones humanas. Lo hizo con palabras, es decir, con un mensaje preciso en el que están integradas las parábolas, con hechos concretos, que vamos a especificar y con signos bien elegidos y cada vez más emocionantes.

\section{Las enseñanzas de Jesús}

Una parte muy importante de las palabras de Jesús sobre la misericordia están formadas por bellos dichos sapienciales y maravillosas parábolas, que son en su conjunto a los que me voy a referir aquí. Dichos y parábolas nos muestran a un Maestro de sabiduría, que sabe llegar a la razón y sobre todo al corazón de sus destinatarios con la destreza de quien tiene una fuerte experiencia de Dios, conoce bien el comportamiento de los hombres y sus palabras están avalada por una vida coherente, en la que existe sintonía entre el hablar y el actuar.

El rico vocabulario griego, que expresa la realidad de la misericordia,

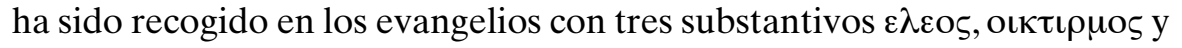

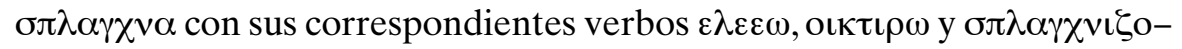

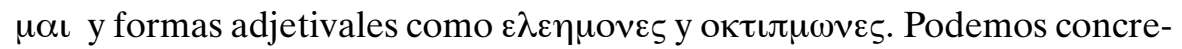
tar su significado aproximado de esta manera: 
- $\mathrm{E} \lambda \varepsilon \mathrm{s} \varsigma$ = éleos designa la bondad, compasión, piedad y misericordia en cuanto implica el sentimiento como tal de enternecerse o conmoverse. No aparece en Mc y Jn; 20 veces en la obra lucana, 15 en Mateo. (Es llamativo su uso en la Carta de Santiago, que significa la reacción práctica ante la situación de necesidad de otro $(2,13 ; 3,17)$.

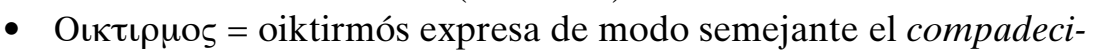
miento, la misericordia en cuanto muestra un sentimiento íntimo, reflejado en el exterior, al contemplar el infortunio de los demás. Testifica entonces la dolorosa exteriorización de la compasión, la lástima y la conmiseración. Aparece de forma muy limitada en Lc 6,36.

- $\Sigma \pi \lambda \alpha \gamma \chi v \alpha=$ splágna puede traducirse por entrañas, vísceras personales, que se conmueven al pasar por el corazón la necesidad ajena. Aquí empalma con la etimología del substantivo «misericordia» (= corazón abierto a la miseria ajena), que significa la cordial conmoción ante la penuria del prójimo. Es el vocablo más cercano al hebreo «rahamim», que expresa el apego instintivo e indestructible de un ser hacia otro. «En la antropología semita este sentimiento íntimo de amor y compasión está localizado en las entrañas, en el seno materno, en el útero. Se comprende que el arquetipo de la misericordia sea el instinto materno» (N. CALDUCH-BENAGES). Nada une más a una persona con otra como el sentimiento de la madre con el feto que lleva en sus entrañas.

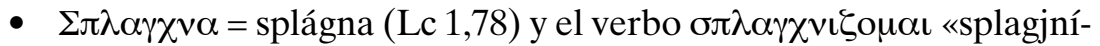
somai» aparecen en los sinópticos de forma bien significativa. Encontramos el verbo en cuestión, en diferentes tiempos, en tres ocasiones en las tres grandes parábolas sobre la misericordia y nueve veces en narraciones de milagros. Tendremos ocasión de mostrarlo.

\subsection{Dichos sobre la misericordia}

Tenemos unos pocos dichos provenientes de Jesús, que han alcanzado notable notoriedad y han determinado el acervo espiritual de todas generaciones cristianas. En ellos la palabra y la realidad de la misericordia juegan una importancia excepcional. Recojo aquí una tríada de dichos, que se alzan en contextos bien significativos: el primero en el Sermón de la Montaña de San Mateo, el segundo resume el Discurso de la Llanura de San Lucas y el tercero lo encontramos en diálogos de disputa, otra vez de San Mateo. 


\subsection{1. «Bienaventurados los misericordiosos ( $\varepsilon \lambda \varepsilon \eta \mu о v \varepsilon \varsigma$ ), porque ellos alcanzarán misericordia ( $\varepsilon \lambda \varepsilon \eta \theta \eta \sigma o v \tau \alpha \iota) »(\mathrm{Mt} 5,7)$.}

La quinta bienaventuranza proclama que lo que realiza el Padre a través de Jesús: el ser misericordioso, constituye el modelo perfecto de las obras de amor, llamadas a ser practicadas por los creyentes conscientes, obedientes y responsables. No olvidemos nunca estas dos cosas: por un lado, las bienaventuranzas representan el exacto reflejo del obrar de Jesús y, por otro lado, pueden ser practicadas como gracia y tarea por los hombres de buena voluntad, que han hecho de Jesús el modelo de su vida y actuación.

Mateo nos inculca que de la misma manera que el Padre y Jesús son misericordiosos, también los cristianos estamos convocados en la Iglesia a practicar la misericordia, acercándonos así tanto al comportamiento del Padre como al de Jesús. La bondad de los misericordiosos, reflejo de la del Padre y Jesús, está cargada de compasión con los que sufren, llena de piedad con los que expresan buenos sentimientos, y sobre todo repleta de misericordia.

Los misericordiosos, a quienes se les llama bienaventurados, necesitan la misericordia de Dios y de su Mesías para poder obrar como tales y devolver amor con amor. Viven de ella de forma permanente y la reflejan con una gran alegría, aliviando las necesidades ajenas y curando sus heridas con efectividad. No juzgan mal a los demás, para no ser juzgados; no pagan mal por mal, porque a ellos sólo se les retribuye con bienes; no condenan al hermano, porque ellos no son condenados; perdonan a los que hacen injusticias, porque son constantemente perdonados por Dios (cf. Mt 6,14s; 18,35).

Vivir así, produce mayor alegría que entregarse de forma egoísta a los placeres, que buscar la posesión de riquezas, por grandes que sean. A quien obra de este modo, Jesús le felicita: ha optado por el Reino y en su acogida encontrará ya la primera recompensa, que le conducirá a la vida feliz.

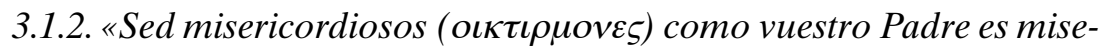 ricordioso» (Lc 6,36).}

San Mateo resume el Sermón de la Montaña, al final de sus famosas antítesis en torno a la ley, con esta frase lapidaria: «Por lo tanto, sed perfectos, como vuestro Padre celestial es perfecto» (Mt 5,48). Palabras claves para entender lo que Jesús propone a quienes quieran seguirlo: vivir la propia existencia desde la actitud íntima del que fija su mirada en el Padre de los cielos y no pone barreras al amor, dado como gracia por el Espíritu. San Lucas ha transformado el dicho en cuestión de modo bien incisivo, que ya hemos 
introducido en el título: «Sed misericordiosos como vuestro Padre es misericordioso». El amor se convierte en misericordia entrañable, en la que la contemplación del dolor, la lástima y la conmiseración se vuelve en regla de vida y principio de actuación.

En realidad se trata aquí de imitar con fidelidad el comportamiento misericordioso del Padre, de modo que pueda recrearse una humanidad nueva, en la que el amor se convierta en la regla suprema. Pero esta actitud misericordiosa no se puede contentar con expresar sin más un sentimiento noble, tiene que llevar a la acción, hacer de ella una tarea permanente, que alcanza tanto a amigos como enemigos, a buenos como a malos, a hombres como mujeres, a judíos como paganos. Este principio de acción tiene la fuerza de poder transformar el mundo.

De hecho transformó a Pablo y a sus discípulos en los primeros tiempos del cristianismo. Uno de ellos pudo escribir a sus fieles, fijada su mirada en Cristo Jesús: «Desterrad de vosotros la amargura, la ira, los enfados e insultos y toda maldad. Sed buenos, comprensivos, perdonándoos unos a otros como Dios os perdonó en Cristo. Sed imitadores de Dios, queridos hijos, y vivid en el amor como Cristo os amó y se entregó por nosotros a Dios como oblación y víctima de suave olor» (Ef 4,31-5,2). Nada hace mejor a personas concretas y comunidades que la actuación misericordiosa, imitando el comportamiento del Señor.

\subsection{3. "Misericordia ( $\varepsilon \lambda \varepsilon \circ \varsigma)$ quiero y no sacrificios" (Os 6,6): que no he venido a llamar a justos sino a pecadores» (Mt 9,13;12,7).}

En la primera parte de su obra San Mateo cita, en dos pasajes bien significativos, unas palabras de Oseas 6,6: «Misericordia quiero y no sacrificios». Importa ciertamente inclinar la cabeza ante Dios, también resulta imprescindible crear espacios de oración, ambiente de plegaria auténtica, de donde brota el encuentro con Dios. Pero hay que dar un paso más. Esto significa que la verdadera adoración de Dios en espíritu y verdad no se encuentra sólo en actos de culto, sino ante todo y sobre todo en mostrar una misericordia compasiva en el trato con los demás, en ejercitar la solicitud amorosa con los débiles y practicar la ayuda efectiva en beneficio de los postrados. Precisamente esto es lo que hace Jesús, sobre todo en su relación con los pecadores y en su comportamiento con los discípulos en estado de necesidad.

Jesús practicó con frecuencia a lo largo de su andadura terrena la $c o$ mensalía abierta. Acogía a toda clase de personas, mal vistas por la buena 
sociedad, y tenía un trato muy especial con los pecadores. Mateo corrobora este hecho constatado por los otros evangelistas y añade algo bien significativo. Jesús está allí donde le necesitan y para conseguirlo incluso se enfrenta con los despiadados fariseos así: «Andad, aprended lo que significa "Misericordia quiero y no sacrificios": que no he venido a llamar a justos, sino a pecadores» $(9,13)$. Los hombres deben aprender a pensar y actuar como lo hace el Padre de los cielos. Y en el pensamiento y actuación de Dios está la complacencia en la misericordia, no en la fría recepción de sacrificios vacíos.

Jesús se saltaba el sábado, cuando así lo imponía la ayuda a los demás (Mc 3,27 par.). Justifica ante los fariseos que sus discípulos arrancaran y comieran espigas en sábado, cosa que no estaba permitida en sábado. Jesús les contesta con gran autoridad: «Pues yo os digo que aquí hay uno que es más que el templo. Si comprendierais lo que significa "quiero misericordia y no sacrificios", no condenaríais a los inocentes. Porque el Hijo de hombres es señor del sábado» (12,6-8). Comprobamos con claridad cómo en la mente y en los pasos de Jesús queda clara la primacía de la misericordia sobre el sacrificio, ya que aquélla, junto con la justicia y la fidelidad, constituye «lo más grave de la ley» $(23,23)$, lo que hay que cumplir por encima de todo. En los relatos de los milagros mostrará cómo la misericordia de Jesús, el Hijo de David, coincide con la misericordia exigida a los humanos.

\subsection{Parábolas}

Pocos como Jesús han escrito en la historia de la humanidad parábolas tan bellas y conmovedoras. Cinco de ellas tienen una especial significación para el estudio de su misericordia. Tres pertenecen a San Lucas, que las ha situado en la parte más importante de su Evangelio, en el camino hacia Jerusalén. Otras dos a San Mateo en sendos discursos: el eclesiástico (cap. 18) y el escatológico (caps. 24-25).

Lucas usa el verbo $\sigma \pi \lambda \alpha \gamma \chi v i \zeta o \mu \alpha \iota$ «splagjnízomai» en sus dos grandes parábolas sobre la misericordia. El verbo tiene un sentido bien activo, que se manifiesta en actos concretos en beneficio de los necesitados. Como ya hemos señalado, significa apiadarse, compadecerse, mostrar entrañas de misericordia.

En la primera de esas parábolas, la del buen samaritano, se resalta la actitud existencial del que está dispuesto a ayudar al prójimo necesitado, poniendo para ello todos los medios que están a su alcance, en este caso tem- 
porales, pero que también pueden integrar esfuerzos, que duren toda la vida. Lo que está en llamativa contraposición con los que «pasan de largo» ante el necesitado, no sintiéndose afectados por la desgracia ajena.

En la segunda, la misericordia del Padre, el verbo resalta la ilimitada misericordia de Dios, que es capaz de olvidarlo todo, perdonar de forma incondicional y tener una alegría infinita ante la recuperación del hijo perdido, vuelto a la casa paterna y a la auténtica vida.

\subsubsection{EI Samaritano misericordioso (Lc 10,30-37).}

El evangelista se ha adentrado en las intenciones de Jesús y quiere que miremos a los prójimos necesitados, por la causa que sea, con su mirada; una mirada que podemos contemplar perfectamente en la descripción que hace del buen samaritano en una de sus más conocidas parábolas.

A diferencia del sacerdote y del levita, insensibles al sufrimiento del prójimo, porque estaban enfrascados en otras ocupaciones, que no se detallan pero que se suponen, este hombre bueno donde los haya y con el corazón en su sitio, se compadeció del que estaba maltrecho al borde del camino con riesgo de perder la vida por culpa de unos infames ladrones. No pasó de largo, no evadió su responsabilidad moral ante el necesitado de verdad, sino que se ocupó de él con un comportamiento, que podemos calificar de admirable.

Conviene que nos concentremos en la descripción de ese comporta-

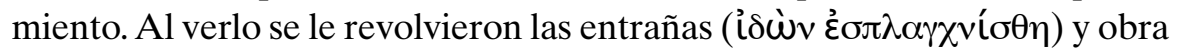
en consecuencia. En un primer momento de urgencia le curó y vendó las heridas, luego le sentó en su cabalgadura y le llevó donde podían atenderlo. Pagó a un posadero, para que se restableciera en su casa hasta que su curación fuera completa. Según esto hizo de la misericordia más generosa el principio de su actuación, mostrando así un amor efectivo y afectivo.

Según San Lucas el profeta de Nazaret ofrece los más auténticos rasgos configuradores de la misericordia, muestra su piedad mesiánica, ya anunciada en tiempos antiguos. Su actividad por los caminos de Palestina refleja en la práctica lo que se narra en la conocida parábola del buen samaritano. Ésta expresa toda su vida mesiánica al servicio de la misericordia, transfigurado como está por la presencia del Padre, que desea lo mejor para sus hijos y está en contra de toda forma de egoísmo e insensibilidad hacia los hombres dolientes. 
Este bello ejemplo nos da la medida de cómo fue el amor del Señor durante su existencia terrena y cómo tiene que ser nuestro amor al prójimo en apuros de la clase que sean. Jesús misericordioso nos invita a cada uno de nosotros a hacer lo mismo, porque el herido al borde del camino es nuestro prójimo, es más: nuestro hermano. No hay principio ético mayor que el amor a Dios y el amor al necesitado, sabiendo que ambos amores reflejan un mismo y único amor.

\subsubsection{La misericordia del Padre (Le 15,11-31)}

Jesús nos ha mostrado como nadie el sensible corazón del Padre, hasta el punto que esta parábola constituye un único en la historia de las religiones. Nos revela algo maravilloso del rostro divino, que nadie nos había mostrado hasta entonces. Dios muestra tanta bondad con los pecadores, que no dejan de ser sus hijos, que «se pasa» con su amor infinito. Se comporta como un padre tan bueno y sensible, que con su desbordante generosidad sorprende a sus hijos, tanto al pequeño como al mayor, en los que nosotros estamos representados.

El hijo pequeño se comporta como un verdadero calavera que, después de gastar toda su herencia y cuando se encuentra con el agua al cuello, no le queda más remedio que regresar a la casa paterna arrepentido. Piensa que su progenitor le recibirá al menos como a uno de sus jornaleros. Pero queda hondamente sorprendido por su comportamiento, que en modo alguno esperaba. El padre bueno, conmovido en sus entrañas $(\dot{\varepsilon} \sigma \pi \lambda \alpha \gamma-$

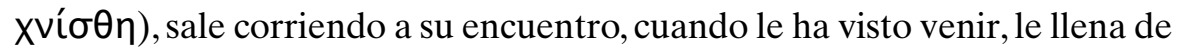
besos, se tira a su cuello y le abraza, le pone un anillo en la mano, le viste con la mejor ropa y, en el colmo de la sorpresa, ofrece a todos una fiesta por todo lo alto, restituyendo a su vástago la dignidad perdida. Proclama a los cuatro vientos: «Celebremos un banquete, porque este hijo mío estaba muerto $y$ ha revivido; estaba perdido y lo hemos encontrado» $(15,23)$.

«Es importante esta enseñanza de Jesús: nuestro condición de hijos de Dios es fruto del amor del corazón del Padre; no depende de nuestros méritos o de nuestras acciones, y por ello nadie puede quitárnosla, jni siquiera el diablo! Nadie puede quitarnos esta dignidad», ha clamado el Papa Francisco con toda razón.

El hijo mayor, obediente siempre a los dictados del padre, tampoco entiende su comportamiento. Le parece totalmente inapropiado que acoja así al hermano pródigo y le muestre un cariño que no le ha mostrado a él, que 
siempre ha permanecido en casa, cumpliendo su deber, y nunca le ha dado un disgusto. Las palabras finales, que le dirige el padre, están dichas también para cada uno de nosotros:

«Hijo, tú estás siempre conmigo, y todo lo mío es tuyo; pero era preciso celebrar un banquete y alegrarse, porque este hermano tuyo estaba muerto y ha revivido; estaba perdido y lo hemos encontrado» $(15,31)$.

¡El hijo mayor también es objeto de la misericordia del Padre! ¡Quiere hacerle comprender que esta misericordia ha hecho posible el milagro: el perdido ha sido recobrado para la familia, el que estaba muerto ha vuelto a la vida! ¡El que odiaba a su hermano, pasa ahora amarlo! ¡La alegría más grande del Padre está en comprobar que sus hijos se reconocen y quieren ya como auténticos hermanos! ¿Puede haber una alegría mayor que esta?

\subsubsection{El siervo inmisericorde (Mt 18,21-35)}

Cinco discursos estructuran el conjunto del Evangelio de San Mateo. El cuarto de ellos, el llamado discurso eclesiástico, ocupa todo el capítulo 18 y en él, entre otras cosas, Jesús inculca a los pertenecientes a la comunidad la práctica de la misericordia en su relación con los pequeños y los pecadores mediante la solicitud por los débiles y el ejercicio del perdón. La misericordia atraviesa todas las indicaciones que aquí se dan a los creyentes. En la vida interna y fraternal de la comunidad hay que evitar algunos peligros graves $(18,6-14)$ y disponerse incluso a cumplir medidas disciplinarias necesarias $(18,15-20)$.

Pero sobre todo hay que poner en práctica con especial fuerza el perdón y la misericordia, hasta el punto que ambas realidades han de estar siempre actuantes en los comportamientos mutuos. Especial significación tiene la parábola final del perdón y la misericordia $(18,21 \mathrm{ss})$, que concluye con esta advertencia a los que no están dispuestos al perdón sincero: «Del mismo hará con vosotros mi Padre celestial, si cada cual no perdona de corazón a su hermano» $(18,35)$.

No hace falta volver a relatar la parábola, sino atender a su mensaje, que ofrece una gran nitidez: El siervo inmisericorde recibió la reprobación de su Señor. Había obtenido un amplio perdón de sus cuantiosas deudas y se esperaba de él, que hubiera tenido compasión del que tan poco le debía. 
No fue así. En este caso concreto la misericordia exigía a todas luces correspondencia. Al instalarse en una postura intransigente y al no estar dispuesto a conceder una moratoria a su deudor, este siervo in inmisericorde se condenó a sí mismo ante los ojos de su Señor, es decir, Dios.

Por último conviene resaltar que el evangelista también usa el verbo $« \sigma \pi \lambda \alpha \gamma X v \iota \sigma \theta \varepsilon i \varsigma »$. Con él se expresa un sentimiento muy fuerte de compasión por parte del señor ante su siervo, que llega incluso hasta perdonarle la cuantiosa deuda debida (versículo 27). Pero también aparece su ira terrible (versículo 34), al comprobar que ese mismo siervo con un comportamiento infame ha renegado de la misericordia divina, al mostrarse despiadado con su consiervo y al no mostrarle semejante compasión, a la que él experimentó por parte de su señor (v. 33). En este versículo se usa el verbo $\varepsilon \lambda \varepsilon \varepsilon \omega$, tener compasión.

\subsubsection{La práctica de la misericordia como criterio del juicio final (Mt 25,31-46)}

Esta parábola ha recibido diversos títulos, pero últimamente uno sobresale por encima de los demás: «el juicio final». Respetando este título quisiera añadir la importancia capital, que en la superación con éxito de ese juicio definitivo tiene la praxis de las obras de misericordia. En el momento decisivo lo que importa ante el Hijo del hombre, que es Jesucristo, el Juez señalado por la Trinidad para juzgar a la humanidad, es rendir cuentas de si se han practicado o no las obras de misericordia. El sentido último de la creación es la vivencia de la fraternidad universal y ese hecho es el que en verdad salvará al mundo.

Lo que verdaderamente importa en la hora final es haber mostrado una actitud de amor ante los necesitados, dejando a un lado toda indiferencia ante ellos o pasar de largo ante sus penurias. El juicio sobre los pueblos abarca a todos y el criterio definitivo para superar con éxito ese momento crucial consiste en haber ayudado a los hermanos pequeños, a los pobres, a los enfermos, a los desnudos, a los encarcelados en la superación de sus miserias y haberlo hecho de manera efectiva. En todos ellos se ve a Dios, con todos ellos se identifica Jesucristo, el Juez Supremo. No valen las buenas palabras, sino las obras de amor, traducidas concretamente en obras de misericordia. La existencia humana está llamada al amor y sólo se salvará en la verdadera respuesta a ese llamada. 
Para finalizar podemos afirmar que en su escrito San Mateo nos muestra, de las manos de su Señor y Maestro, que la misericordia como ninguna otra realidad nos abre el corazón al Padre y a los hermanos $(23,8.9)$; hasta el punto que la credibilidad de nuestro amor pasa necesariamente por la experiencia de esa misericordia entrañable, que parte del Padre para bien de todos los humanos. ¡Qué dulce es dejarnos tocar por Jesús en el gozo del silencio orante, para respirar su misericordia, que nos comunica de parte del Padre y simplemente ser creyentes y expectantes ante su persona! ¡Cómo no contemplar agradecidos su amor, que se derrama sobre nosotros, para enriquecer nuestra existencia con la alegría de vivir! ¡Cómo no imitar su bendita misericordia con nuestros semejantes, acogiendo a los otros de la misma manera que Él lo hace!

\subsubsection{El fariseo y el publicano (Lc 18,9-14)}

La parábola tiene como contenido la práctica de la oración de dos personas, que pertenecen a estamentos socio-religiosos contrapuestos: El primero, un fariseo que se tiene por bueno, reza mal. El segundo, un publicano que se considera pecador, reza de la forma debida. Pues bien, Dios derrama su justicia sobre este compungido publicano, que se presenta ante Él tal como es, sin falsos fingimientos. Arrepentido y hasta anonadado, reconoce la maldad de sus actos y espera que Dios acepte su corazón contrito. Su breve pero intensa oración está orientada hacia la radical confianza en la misericordia divina, que puede ofrecerle el perdón. Con su sinceridad sin aspavientos encuentra el beneplácito de lo alto.

En cambio rechaza por falsa la acción de gracias de un fariseo engreído, que se complace de forma desmedida en sus buenas obras, desprecia a los demás y no busca el encuentro humilde con el Señor sino ser ensalzado por su pretendida rectitud moral. De hecho no pretende tanto dialogar con Dios como exhibir su engreimiento. Lo que le importa en realidad es su propio yo (todo gira en torno a él), no el conocimiento de la voluntad divina y la súplica de su misericordia. Con su vacía vanagloria se hace merecedor de la repulsa del que conoce bien la verdad interior de las personas. En la época de Jesús se daban con frecuencia oraciones de este tipo, que pueden leerse tanto en los escritos de Qumran como en el Talmud. He aquí un ejemplo: "Te alabo, Señor, que no has dejado caer mi suerte en la comunidad vana y no has colocado mi parte en el círculo de aquellos que están a escondidas" (1Q H 7, 34). 
La confesión de sus pecados y la solicitud de la misericordia divina justifican al recaudador, mientras que la actitud legalista de quien se considera justo es rechazada. A los ojos de Dios el pecador queda rehabilitado, porque con su humilde y contrita oración ha puesto su confianza en la gracia divina, le duele su comportamiento y es consciente de su condición pecadora. Mientras que el que se considera justo con poses de autosuficiencia, no encuentra el beneplácito divino, porque con su desorientada moralidad se fía exclusivamente de sus obras, se aísla de los demás, lejanos y cercanos, y su oración, en lugar de buscar el encuentro humilde con Dios se desvía por caminos erráticos, que le apartan de la justicia divina. Dios da un sí rotundo al pecador con "un corazón contrito y humillado" (Sal 51,19), mientras que dice no al justo ante sus propios ojos, pero no ante los de Dios, ya que en realidad es un auténtico engreído. Justo, verdaderamente justo ante Dios, no es, por lo tanto, el que cumple puntualmente las observancias, sino el que, fiándose de la misericordia divina, reconoce su propia limitación y confiesa sinceramente su pecado. Actitud orante se da en aquel que se encuentra con el Padre tal como es: desvalido en su condición pecadora y necesitado una y otra vez de su gracia y misericordia.

Es bien significativo, cómo cuatro de los grandes teólogos, que yo conozca, del siglo XX, K. RAHner, K. BARTh, H. Küng y O. GonZÁlez de CARDEDAL, coinciden en presentar la oración del publicano como la suya propia en la hora final. Cuando sean llamados por Dios en el acontecimiento de la muerte sólo querrán y podrán balbucir esta sincera y humilde plegaria. «...Me presentará allí con las manos vacías y sólo me parecerá oportuno decir: "Dios, ten misericordia de este pobre pecador" », confiesa K. BARTH. «O sea, lo que decía el publicano allá al fondo del templo, y que desde entonces yo espero que sea también mi última palabra», comenta $\mathrm{H}$. KÜNG a la esperanzada confidencia, que en su día le hizo su admirado amigo K. BARTh (H. KüNG, Libertad conquistada. Memorias. Madrid $\left.{ }^{3} 2004,196\right)$. Por su parte, el primero de los mencionados añade estas oraciones: «Te pido la gracia de la perseverancia. Me concederás tal don en la medida en que yo permanezca firme en el gozo de tu misericordia» (K. RAHNER, Oraciones de vida. Madrid2 1989, 195). «Una vez me hablarás en mi muerte y después de mi muerte [...]. Oh Señor, déjame entonces en mi muerte escuchar palabras de tu perdón y del amor, que yo no desoiré» (ID, Heilige Stunde und Passionsandacht. Friburgo - Basilea - Viena ${ }^{3}$ 1954, 42). También el gran teólogo castellano O. GONZÁLEZ DE CARDEDAL se expresa en términos parecidos: "Entonces levanto mi alma y digo: Señor, cuando llegue el momento acógeme y mírame con misericordia. A él le concedo más crédito 
que a mí mismo" (C. EYMAR, «Olegario el Teólogo»: El Ciervo 51/ 672 [2007] $31)$.

\subsection{Hechos de misericordia}

Los estudiosos destacan tres hechos fehacientes en la historia de Jesús, que tuvieron especial significación en su actuación pública al servicio del reino: el llamamiento al discipulado, los milagros y el trato con las mujeres. En todos ellos brilla la misericordia con luz propia.

\subsubsection{Llamamiento de Leví-Mateo (Mc 2,15-17; Mt 9,9-13; Lc 5,27s)}

Los llamamientos de Jesús al discipulado fueron frecuentes en la primera etapa de su vida pública. No podemos enumerarlos todos, para no descompensar esta sección. Ya lo he hecho en otra parte. Bien significativo es el del hombre rico (Mc 10,17-22; Mt 19,16-22; Lc 8,18-23), que se acercó a Jesús, para preguntarle que debía hacer «para heredar la vida eterna». Marcos afirma que le miró con ternura y «lo amó» $(10,21)$; pero al final rechazó la oferta misericordiosa de Jesús, porque estaba enredado en sus cuantiosos bienes.

Aquí me voy a referir sólo a uno de esos llamamientos de tradición triple, el de Leví, Mateo, que en nuestro Papa actual ha tenido una remarcada relevancia, como ya hemos señalado en otra exposición. Parto de las palabras de Beda el Venerable, un gran sabio y santo, que comprendió en profundidad el significado de este acontecimiento: Jesús contempló a Mateo, el publicano, «más con la mirada interna de su amor que con los ojos corporales... Le dijo "Sígueme", más que con sus pasos, con su modo de obrar. Porque quien dice que está siempre en Cristo debe andar de continuo como Él anduvo». Lo que atrajo a Mateo fue la luz de la misericordia, que experimentó en el acontecimiento de la llamada al seguimiento en una opción fundamental, que iba a transformar radicalmente su existencia.

Mateo se levantó y lo siguió. Lucas afirma que «dejándolo todo». «No hay que extrañarse del hecho -sigue comentando el santo inglés-de que aquel recaudador de impuestos, a la primera indicación imperativa del Señor, abandonase su preocupación por las ganancias terrenas y, dejando a un lado todas sus riquezas, se adhiriese al grupo que acompañaba a aquel que él veía carecer en absoluto de bienes. Es que el Señor, que le llamaba por fuera 
con su voz, lo iluminaba de un modo interior e invisible para que lo siguiera, infundiendo en su mente la luz de la gracia espiritual, para que comprendiese que aquel que aquí en la tierra lo invitaba a dejar sus negocios temporales era capaz de darle el Cielo un tesoro incorruptible».

No cabe duda que en esta admirable reflexión encontramos mucho de espiritualidad cristiana, que va más allá de lo acontecido en el momento del seguimiento. Pero capta algo histórico en el comportamiento de Leví: Se sintió irresistiblemente atraído por alguien, que estaba mostrando una gran autoridad sobre él, y le miraba con una gran misericordia, al entrar a saco en su vida. Experimentó que con la gracia de su amor le estaba liberando de unas ataduras, que le impedían ser sincero consigo mismo y obrar como una persona de verdad.

\subsubsection{Los milagros}

Que Jesús obró verdaderos hechos maravillosos está fuera de toda duda. Aquí voy a referirme tan sólo a tres de ellos, en los que la misericordia juega una especial significación. Posiblemente sea San Marcos el evangelista, que mejor recoge las características históricas de los milagros de Jesús. De ahí que recurramos sobre todo a él, para detallar su presentación.

\subsubsection{La curación del leproso (Mc 1,40-45)}

Así de escueto narra San Marcos lo esencial de lo sucedido en este singular hecho: «Se le acerca un leproso, suplicándole de rodillas: "Si quieres, puedes limpiarme". Compadecido extendió la mano y le tocó diciendo: "Quiero: queda limpio". La lepra se le quitó inmediatamente y quedó limpio».

A Jesús se le parte el corazón el contemplar a aquel hombre abatido, que estaba viviendo como un apestado, sin relación alguna con los demás. No olvidemos que los leprosos, hasta tiempos bien recientes y mucho más en aquella época, eran echados de sus casas, por el peligro de contaminación que suponía su contacto con los otros. La misma ley de Moisés prescribía su expulsión de la comunidad.

Jesús está por encima de esas convenciones sociales y legales. Por eso se compadece del pobre rechazado y extiende su mano, tocándolo con cariño. Al instante queda curado por su palabra sanante, llena de la autoridad 
divina. Ante algo escandaloso, que no corresponde al plan divino de salvación sino al egoísmo de la sociedad, Jesús actúa en consecuencia, con la libertad propia del enviado de Dios a la humanidad caída en el pecado.

Conviene que nos detengamos en la eficaz descripción del evangelista: a) Primero se le revuelven las entrañas (ese es significado más correcto para el verbo griego que usa el evangelista $\sigma \pi \lambda \alpha \gamma \chi v i \zeta o \mu \alpha \iota$ y que aquí se traduce por compadecido), haciendo suyo el dolor de aquel desgraciado, excluido de sus semejantes. Es en las mismas entrañas donde se localiza el sentimiento, la emoción y la conmoción, que produce la misericordia.

Después pasa a la acción y toca lo intocable sin miedo alguno. No tiene miedo a quedar impuro (como proclamaba una ley inhumana) o a ser contaminado (como atestiguaba la cruel medicina). En nombre y en lugar de Dios lo libera de su mal, le restablece la dignidad perdida y le convierte de nuevo en una persona de verdad. El amor compasivo y misericordioso de Jesús obra la maravilla de hacer de un no-hombre un hombre de verdad, de un excluido un integrado en la sociedad. ¿No podemos hacer algo parecido nosotros como discípulos, a quienes Cristo necesita para poder seguir obrando milagros en este mundo?

El amor compasivo y misericordioso de Jesús rompe tabúes y obra la maravilla de restablecer a un relegado de los bienes sociales en todos los derechos y en la exigida dignidad.

\subsubsection{El hombre de la mano atrofiada (Mc 3,1-5).}

«Entró otra vez en la sinagoga y había allí un hombre que tenía una mano paralizada. Lo estaban observando, para ver si curaba en sábado y acusarlo. Entonces le dice al hombre que tenía la mano paralizada: "Levántate y ponte ahí en medio”. Y a ellos les pregunta: “QQué está permitido en sábado?, ¿hacer lo bueno o lo malo?, ¿salvarle la vida a este hombre o dejarlo morir?". Ellos callaban. Echando en torno una mirada de ira y dolido por la dureza de su corazón dice al hombre: "Extiende tu mano". La extendió y su mano quedó restablecida».

Conviene destacar los sentimientos, que nacen de Jesús ante esta situación y que en realidad constituyen una consecuencia de su continuada actuación misericordiosa. Se siente dolido y lleno de justa ira por la insensibilidad que muestran aquellos hombres duros de corazón, que no se hacen cargo del sufrimiento de aquel desgraciado, que tiene la mano atrofiada 
y está en peligro de perder su vida. No saben leer la actuación bondadosa de Jesús y se cierran a su amor misericordioso.

Pero el Señor no se deja afectar por comportamiento tan reprobable y obra con la autoridad, que su Padre le ha proporcionado para estos casos. Y así, siguiendo su camino de compasión y misericordia con toda clase de pobres, cura al pobre atormentado. Anteriormente había proclamado: "El sábado se hizo para el hombre y no el hombre para el sábado; así que el Hijo del hombre es señor también del sábado» $(2,27)$. La potencia del amor de Jesús supera con mucho una observancia inhumana de la ley.

Ante el proceder infame de esos hombres, tan respetados por el pueblo, pero tan poco abiertos a sentir en su corazón el dolor ajeno, Jesús no puede contenerse. Le duele en el alma que los que se están convirtiendo en sus enemigos irreconciliables, que le llevarán a la cruz, se refugien en leyes inhumanas, para ocultar su falta de compasión con los enfermos. En lugar de solidarizarse con Jesús y aplaudir su actuación, traman su perdición.

\subsubsection{El ciego Bartimeo (Mc 10,46-52)}

La escena, que con bastante seguridad refleja una realidad histórica observada con precisión, es bien conocida y tiene lugar en la ciudad de Jericó, la última etapa del viaje del Nazareno con los suyos a Jerusalén. Un ciego, se entera de que Jesús está pasando a su lado. Posiblemente el autor del relato conoció a Bartimeo, de ahí que conservara su nombre.

Como aquél conoce su poder taumatúrgico «empezó a gritar: "Hijo de David, Jesús, ten compasión de mí". Muchos lo increpaban para que se callara. Pero él gritaba más: «Hijo de David, ten compasión de mí». Jesús se detuvo y dijo "Llamadlo". Llamaron al ciego, diciéndole: "Ánimo, levántate, que te llama”. Soltó el manto y se acercó a Jesús. Jesús le dijo: “¿Qué quieres que te haga?". El ciego le contestó: "Rabbuni, que vea”. Jesús le dijo: "Anda, tu fe te ha salvado"».

La súplica, dirigida al Hijo de David, contaba con una gran tradición en el ámbito judío y puede verse corroborada también en Mt 15,22 y 17,15. El Mesías aparecería ante su pueblo como un personaje carismático, revestido de sabiduría, autoridad para enseñar y curar y también dotado de una gran compasión. Figura tan singular estaba obligada a prestar ayuda pronta al necesitado. El encuentro, que tiene en un primer momento dificultades para producirse, propicia un diálogo corto, pero de inusitada in- 
tensidad. La breve conversación entre los dos protagonistas va a lo esencial y el hecho maravilloso se produce.

En este enternecedor relato el ciego busca la misericordia de Jesús y la encuentra con creces. Se produce el milagro de modo que, el que caminaba en tinieblas, recobra la luz. Su gran fe le ha hecho «ver» que Dios ha tenido compasión de su ceguera y, a través de su enviado, el Mesías Hijo de David, ha obrado el milagro que tanto ansiaba. Tan resarcido se siente el interesado, que se convierte enseguida en discípulo de Jesús. La luz que ha recibido, la física y la de la fe, quiere testimoniarla delante de los demás. Ha logrado integrarse en la comunidad de Jesús. Y así recobrada la vista, «le seguía en el camino».

(Dejamos a un lado la curación de los dos ciegos de Mt 20,29-34. En el último versículo se constata que «compadecido (esplanjniszeìs) Jesús les tocó los ojos, y al punto recobraron la vista y lo siguieron». Ya hemos explicado el significado de ese verbo).

\subsubsection{Acciones de Jesús, compadeciéndose de las necesidades ajenas}

Antes de la primera multiplicación de los panes y de los peces: «Jesús vio una multitud y se compadeció de ella, porque andaban como ovejas que no tienen pastor, y se puso a enseñarles muchas cosas» (Mc 6,34; Mt 9,36; 14,14). Al comenzar la segunda multiplicación, «Jesús llamó a sus discípulos y les dijo: "Siento compasión de la gente, porque llevan ya tres días conmigo y no tienen que comer" ( $\mathrm{Mc} 8,2 ; \mathrm{Mt} 15,32$ ). El padre del muchacho, que tenía un tenía un espíritu inmundo le dice a Jesús: «Si algo puedes ten compasión de nosotros y ayúdanos» (Mc 9,22). Y Jesús realiza el milagro). En todas estas escenas, en las que están presentes diferentes acciones ma-

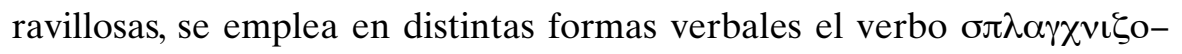
$\mu \alpha \iota$ «splagchnizómai».

\subsubsection{Comportamiento con las mujeres}

El paso de Jesús por la Palestina del primer tercio del siglo primero de nuestra era supuso una historia cargada de luz y esperanza, todo un acontecimiento salvador mediante el descubrimiento definitivo del Dios de la misericordia y mediante la liberación física de males, que siempre han 
oprimido al hombre y de los que nunca ha podido liberarse. Su presencia luminosa y bienhechora no pasó desapercibida en la sociedad de su tiempo.

Este hecho fehaciente queda de manifiesto de un modo muy especial en su singular trato con las mujeres, a las que jamás dirige palabras de reproche, como otros contemporáneos suyos y la generalidad de los escritores de la Antigüedad. Bien al contrario, se sintieron acompañadas por su expresiones acogedoras y sus signos liberadores. Les produjo una atracción tan irresistible, que algunas de ellas, insatisfechas en su existencia de cada día, lo siguieron en el camino como discípulas tanto en Galilea, como en la odiada Samaría y en la admirada Judea.

Sobre todo las mujeres más desamparadas se sintieron resarcidas en su desvalimiento a través de sus palabras eficaces y sus signos maravillosos, que incluso llegaron a superar la muerte. Todas ellas experimentaron su fuerza sanadora, liberadora y resucitadora. En la tradición evangélica contamos con algunos entrañables encuentros del profeta de Nazaret con mujeres, que nos ayudan a conocer perfectamente su interior misericordioso.

Llama especialmente la atención, que siempre emplea con ellas palabras de acogida (como es el caso de la samaritana), de consuelo y apoyo (la viuda de Naín), de cariño y alivio (la pecadora), de perdón incondicional (la adúltera), de misericordia (la hemorroisa), de vida (la hija de Jairo), de liberación (la encorvada). Y esto es lo que vamos a ver ahora aquí de la mano de este ramillete de ejemplos bien característicos.

\subsubsection{La hemorroísa y la hija de Jairo (Mc 5,21-43)}

Los evangelistas presentan tres resurrecciones obradas por Jesús. La resurrección de la hija de Jairo aparece en los tres Sinópticos. La del hijo de la viuda de Naín sólo en Lucas. La de Lázaro es propia del Cuarto Evangelio. Las tres coinciden en presentar a Jesús, el Resucitado de entre los muertos, como el que se muestra capaz de transmitir la vida en nombre de Dios, poniendo en práctica una misericordia llena de matices sanantes. Lo característico de la primera consiste en desarrollar con un manifiesto interés historizante su exposición, concatenándola a otro milagro, la curación de la hemorroísa.

La resurrección de la hija de Jairo tiene sorprendentes paralelos, con la resurrección del hijo de la viuda de Sarepta, realizada por el profeta Elías (1 Re 17,17-24), y con la resurrección del hijo de la sunamita, obrada por su discípulos Eliseo (2 Re 4,29-37). Ambos textos constituyen los prece- 
dentes literarios y teológicos del portento que tratamos ahora. Pero Jesús es presentado aquí como mayor que Elías y Eliseo, obrando con un poder sobre la enfermedad y la muerte muy superior a ellos. De hecho resucita a la hija de Jairo sin tener que recurrir a acciones complicadas, como en el caso de ambos profetas, tan celebrados en Israel.

El poder sobrenatural que caracteriza a Jesús posee tanta grandeza que con sólo ordenarlo se produce la maravilla de la resurrección de la niña. Con su palabra tajante y poderosa, recogida en el idioma original, «Talitha kumi», logra lo increíble, el paso de la muerte a la vida, sin necesidad de ejecutar más gestos. Jesús obra con el mismo poder divino, manifestando así de manera plena la bondad de Dios para con los hombres. Su unión íntima con el Padre tiene la fuerza sanante y liberadora de realizar las obras exclusivas del Todopoderoso, el único capaz de conferir vida verdadera. Sus palabras soberanas producen lo que significan. Lo mismo que Dios.

Pero entendamos bien el comportamiento de Jesús. No realiza sus prodigios para aumentar su prestigio como taumaturgo y de este modo aparecer entre las gentes como una persona con dotes extraordinarias, digna de ser admirada por todos y de recibir los aplausos de la multitud. Los milagros de Jesús, como signos fehacientes del reino que son, siempre tienen como finalidad el abrir a los hombres a la misericordia divina, hacerles conscientes de que, a través de él, su intermediario en este mundo necesitado, se está revelando la gloria del Padre, que quiere siempre que los hombres tengan vida en plenitud. En este sentido la resurrección de la hija de Jairo constituye un ejemplo bien demostrativo de lo expresado.

Pero también lo es la curación de la hemorroísa. La confianza ilimitada de la pobre enferma en el poder de Jesús, lo mismo que la súplica confiada de Jairo, suponen bien a las claras la fe en Jesús, tanto que en muchas ocasiones se atribuye a esa fe la acción salvadora, siendo por ella posible lo que humanamente parece imposible (Mc 9,23). Por eso Jesús, después de haberse «encontrado personalmente» con la asustada mujer y tranquilizarla, le dice con una gran ternura: «Hija, tu fe te ha curado. Vete en paz y con salud».

Precisamente es esta fe la que, no parando en Jesús, abre a Dios. La disposición de absoluta confianza en Jesús salvador constituye la condición necesaria para la apertura al Omnipotente. Jesús se convierte así en una parábola de Dios. Su persona, vida, palabra y, sobre todo sus acciones maravillosas, hablan del Todopoderoso, remiten siempre a Él, que se muestra así, mediante la actividad pública de su elegido por las aldeas de Gali- 
lea, no sólo como Creador y Señor del mundo sino también como dispensador de vida para los hombres y garante de su felicidad.

Encontrarse con Jesús significa tanto como encontrarse con el poder salvador del mismo Dios, siempre abierto a las necesidades humanas, siempre dispuesto a conceder vida allí donde reina la muerte, siempre deseoso de transmitir esperanza a los que se han cansado de esperar, por no obtener los apetecidos resultados prácticos. El comportamiento de Jesús representa todo un aliciente para cada uno de los cristianos. Él se acreditó como el gran colaborador de Dios en la obra de donar vida en abundancia y quiso que los creyentes continuáramos en su nombre esta misión.

Cada uno de los cristianos no puede contentarse con esperarlo todo de Jesús mediante la confianza total de su persona y la aceptación de sus beneficios, tiene que aprender de su persona y comportamiento también, para convertirse en transparencia de Dios en beneficio de los demás, sobre todo de los necesitados, y al servicio de los que piden a gritos que se les transmita vida. No olvidemos las palabras solemnes de Jesús, llenas de realismo, para los que confían en su palabra y están dispuestos a proseguir su causa: "Os aseguro que el que cree en mí, hará también las obras que yo hago. Hará aún cosas mayores, porque me voy al Padre» (Jn 14,12). Y en el mundo deja a los continuadores de su obra.

Jesús está ahora junto al Padre y cada uno de nosotros estamos llamados a ser como Jesús, a obrar como él lo hizo, convirtiéndonos también en parábolas del Padre en nuestro trato con los hombres, sobre todo con los hambrientos de vida y los necesitados de consuelo del tipo que sea. Quien quiera encontrar la vida y colaborar también con ella tiene que atenerse a las palabras y acciones de aquél a quien Dios resucitó de entre los muertos y tiene pleno y permanente poder sobre la vida y la muerte.

Con su palabra poderosa y liberadora, llena de misericordia, Jesús abre a la hemorroisa a una nueva vida sin dolor, sin vejaciones y proporciona vida a la hija de Jairo, que estaba muerta. En su obrar se está manifestando que la misericordia del Padre no tiene límites. Va más allá de lo que humanamente puede imaginarse, quien es objeto de un amor tan grande.

\subsubsection{La viuda de Naín (Le 7,11-17)}

Nos encontramos en Naín, una minúscula población de la Baja Galilea, cercana a Nazaret. Seguro que Jesús había visitado la aldea en otras ocasiones y en circunstancias normales. No suelen suceder hechos extraordi- 
narios en lugares tan pequeños. Pero esta vez el pueblo estaba conmocionado, ya que «sacaban a enterrar a un muerto, hijo único de su madre, que era viuda». Por las palabras de Jesús sabemos que tan sólo era un joven, a quien su madre necesitaba, sobre todo en aquel momento en que no contaba con el apoyo de su marido. La situación caló en lo hondo del corazón de Jesús. Al contemplar la desgarradora escena, al Señor «le dio lástima».

Conviene que comentemos dos palabras claves del texto griego: el substantivo «Señor» y el verbo «dar lástima». En ambas palabras descubrimos el misterio de salvación que envuelve al Nazareno y su capacidad para transformar cuanto le rodea. El nombre de «Jesús» ha sido sustituido aquí por el de «Señor», algo que Lucas hace en múltiples ocasiones, cuando quiere resaltar su grandeza y fuerza de arrastre, poniéndolo en su propia redacción y en boca de quienes se acercan a él o viven con él $(5,8 ; 7,6$; 9,54.59.61; 10,1.17.39s; 11,1.39; 12,41s; 13,23; 17,5; 18,6.41; 19,8; 19,31; 22,33.38.49.61; 24,3). La compasión constituye una de las emociones más acentuadas en la actuación de Jesús, sobre todo en las narraciones lucanas, cuando se encuentra con las personas para ayudarlas. Pero entendámosla bien. No se trata de una com-pasión pasiva, sino activa. Jesús sufre con la pobre viuda y hace de su dolor el principio de su orientación y sobre todo actuación. Lo que le lleva a pasar a la acción, con-movido como está.

Jesús no sólo sana toda clase de enfermedades, también puede resucitar a los muertos mediante acciones especialmente maravillosas. Como los grandes profetas de Israel, como Elías y Eliseo, devuelve la vida en nombre de Dios al hijo de una pobre viuda. Con todo, su poder excede a aquéllos y su autoridad los sobrepasa con mucho. Sin más recursos, basta su palabra soberana para producir el prodigio: « $i M u c h a c h o$, a ti te digo, levántate!».

La palabra creadora de Dios reside en Jesús, identificándose con la Palabra con mayúscula (Jn 1,1ss). Esta Palabra realiza las obras mismas del Altísimo. Su fuerza efectiva está capacitada para obrar signos demostrativos del reino, incluso proporcionar, lo que parece del todo imposible: vida a los muertos. Con sencillas, pero claras indicaciones el evangelista constata la eficacia de las palabras empleadas por el Señor: «El muerto se incorporó y empezó a hablar».

Y añade: «Y Jesús se lo entregó a la madre». Jesús tiene en cuenta al hijo, pero sobre todo a la madre. Ella es la que recibe el principal de los consuelos, el mayor de los regalos: al hijo nacido de sus entrañas y vuelto a la vida por designios divinos y obra del Profeta de los profetas, que ha obrado 
con una gran misericordia. De ahí que los presentes sobrecogidos griten con admiración: «Un gran Profeta ha surgido entre nosotros».

Las acciones de Jesús superan con creces a los mayores portavoces divinos del Primer Testamento. De hecho para Lucas, y también para los creyentes lectores del Evangelio, Jesús se acredita con sus hechos y palabras como el Profeta último y definitivo, que inaugura los tiempos decisivos, en los que lo nuevo deja sin vigencia a la viejo, en los que la muerte da paso a la vida.

Importa aquí y ahora actualizar entre nosotros el prodigio de Jesús, síntoma de algo radicalmente nuevo que alcanza de lleno nuestra vida. Vivimos en la era escatológica, abiertos a la esperanza cierta de que con Jesús todo se renueva y todo adquiere la fuerza de la vida. Quien cree en su persona posee ya la vida eterna y no experimentará el desastre final (Jn 5,24ss). Estamos llamados no a la perdición, sino a la salvación. A cada uno de nosotros Jesús nos llama por nuestro nombre y nos insta: ¡A ti te digo, levántate! ¡Vive, deja a un lado el pecado, el mal, la muerte! La misericordia de Jesús obra el gran milagro y la pobre viuda de Naín recobró la perdida esperanza y las ganas de vivir, al contemplar de nuevo a su joven hijo, vuelto a la vida.

\subsubsection{La pecadora en casa de Simón (Lc 7,36-50)}

Nos encontramos ante una estampa memorable sobre la mujer, anclada en la historia de Jesús, y exclusiva de Lucas, el gran cantor de la misericordia divina. Este encuentro de Jesús con la mujer pecadora está narrado en contraste, para resaltar su excelente proceder con ella, a pesar de pertenecer a la peor de las sociedades de aquel tiempo, al grupo denostado de las prostitutas. La escena acontece en un lugar indeterminado de Galilea y se desarrolla en el marco de una de las muchas comidas, que Jesús tuvo con toda clase de personas.

En esta ocasión ha sido invitado por un respetable fariseo, del que conocemos su nombre, Simón, aunque su comportamiento como anfitrión deja mucho que desear. Da la sensación que su invitación se ha debido más al puro compromiso que a la expresión de afecto y reconocimiento hacia el Maestro de Nazaret. Algunos piensan que había sido sanado por él.

Aquel hombre, quizá de corazón duro, se asombra y critica para sus adentros a Jesús, cuando se percata con asombro de que, en el transcurso de la comida, una mujer se le acerca, regando los pies con sus lágrimas, en- 
jugándoselos con sus cabellos, cubriéndolos de besos y ungiéndolos con perfume. Semejantes tocamientos le parecen fuera de lugar, sobre todo viniendo de una mujer de mala vida. Un verdadero profeta no puede consentir que una pecadora pública tenga semejante comportamiento en el marco festivo de una comida entre personas de la buena sociedad.

No nos tienen que extrañar demasiado los pensamientos de Simón, cuando se conoce el modo de pensar y obrar de sus correligionarios, los fariseos en la sociedad judía de aquel tiempo. Su espiritualidad cerrada exigía una separación total entre los que se tenían por buenos y los que eran marcados con la etiqueta de malos. La parábola del fariseo y el publicano, de la que ya hemos hablado, nos suministra preciosa información al respecto. Merece la pena pararse en ella, para poder entender en su justa medida el comportamiento de Jesús con la pecadora.

Escuchemos ahora las palabras, que dirige a su interlocutor: «Jesús dijo a Simón: “¿Ves a esta mujer? He entrado en tu casa y no me has dado agua para los pies; ella, en cambio, me ha regado los pies con sus lágrimas y me los ha enjugado con sus cabellos...Por eso te digo: sus muchos pecados han quedado perdonados, porque ha amado mucho"».

Jesús pone en la picota la actitud de este hombre despiadado, que conoce con exactitud la literalidad de las leyes, pero olvida el espíritu de misericordia, que deben informarlas, para contar con el beneplácito divino. Para Jesús importa sobre todo el arrepentimiento y el amor. Y esa mujer ha derrochado ambos con creces. Por eso, con toda la ternura, le perdona sus pecados en nombre del Padre y alaba también su fe, ya que contempla en Él al enviado de Dios para salvar a los extraviados. Porque ha amado mucho se le ha perdonado también en demasía. La misericordia de Jesús regenera a una mujer, siendo capaz de penetrar en su corazón, lleno de amor.

Quienes comen con Jesús el profeta están llamados a tender la mano de buena gana a quienes se arrepienten y son perdonados, como gesto de sincera reconciliación. Teniendo siempre muy presente que la acogida de los pecadores constituye un proceso constante en la propia conversión a Dios (Lc 15). Si Jesús lo hizo así ¡cómo no hacerlo quienes somos sus discípulos y seguimos su actuación, que refleja el comportamiento divino!

La comunidad cristiana es invitada aquí a adoptar una actitud semejante a la de Cristo: acoger con ternura al pecador arrepentido, abrirle el perdón incondicional en nombre de Dios y derrochar con ellos el mismo amor que el Padre tiene con los débiles y tambaleantes. Nada más extraño al espíritu del cristianismo que la insensibilidad ante los pequeños y la dureza de corazón para con los pecadores. 


\subsubsection{La mujer encorvada (Lc 13,10-17)}

El milagro tiene lugar en una sinagoga, en una población no identificada, cuando Jesús iba de viaje hacia Jerusalén. Desde hacia dieciocho años una pobre mujer «estaba enferma a causa de un espíritu, y estaba encorvada, sin poderse enderezar de ningún modo. Al verla, Jesús la llamó y le dijo: "Mujer, quedas libres de tu enfermedad". Le impuso las manos, y enseguida se puso derecha. Y glorificaba a Dios».

Dios ha puesto a Jesús en el camino de esa mujer, para que la liberara de las ataduras del mal, que le impedía comportarse como una verdadera persona. La acción de Jesús, por lo tanto, corresponde al plan divino de salvación, como se constata en la fórmula gramatical $\delta \varepsilon \tilde{u}$, del versículo 16. En las palabras de Jesús, contenidas en este versículo encontramos la cima del relato. En ellas se expresa la intencionalidad más íntima de Jesús en la realización del portento.

El bienestar de las personas concretas, y más si se encuentran desprotegidas, tiene en él una prioridad absoluta. Está por encima incluso del cumplimiento de la ley del sábado. Cualquier precepto legal deja de tener sentido, cuando no se pone al servicio de las personas. Una vez más resuena aquí: «el Hijo del hombre es señor del sábado» (Lc 6,5 par.). Y aún más todavía: «El sábado ha sido hecho para el hombre, y no el hombre para el sábado» (Mc 2,27).

La narración destaca una idea preponderante: a través del único y definitivo profeta, cargado de piedad y misericordia, Dios endereza los cuerpos y libera a las personas en peligro de disolución de su dignidad. El que la destinataria de la acción portentosa sea una mujer no deja de contener una alta significación. Nos está indicando la predilección de Dios y de su emisario por las mujeres, ya que aparecen como las personas más desprotegidas de la sociedad, las más necesitadas del amparo divino. El Salvador escoge con toda intención curar a una mujer para desenmascarar al jefe de la sinagoga, más proclive a estancarse en leyes caducas que sensible a las necesidades ajenas, aunque fueran consideradas por él como personas de segunda categoría.

Sanar el sufrimiento le importa a Jesús, sobre todas las cosas. En ese momento concreto incluso lo antepone a anunciar la Palabra de Dios. No quiere que las personas pequeñas, humildes estén afligidas, sino que sean felices. Su misericordia tiene aquí uno de los rasgos más sobresalientes, más esenciales en el desarrollo de su misión. Sin la extirpación del dolor físico y espiritual, moral y social no puede haber compasión de verdad. La bon- 
dad de Dios, que testimonia Jesús con sus acciones maravillosas, quiere sanar todas las enfermedades.

Es el caso concreto de esta mujer, aquejada de una pesadez insufrible, que le impide ser como los demás por estar doblada. Liberada de su mal, puede vivir como una persona libre, enderezada en su dignidad, dispuesta a alabar a Dios, que cumple sus promesas y tiene piedad de sus fieles, pero también de todos los hombres. Una vez más Lucas presenta a Jesús lleno del poder del Espíritu, puesto al servicio de los desamparados. En este caso concreto se trata de una pobre mujer, que es sanada en un ambiente y tiempo bien llamativos: en la sinagoga y en sábado. La mujer, que había venido a escuchar la Escritura, acaba alabando a Dios.

La buena mujer ha percibido perfectamente que a través de Jesús es el mismo Dios quien está obrando en ella; por eso, después de enderezarse, «se puso a alabar a Dios». Lo que no capta el engreído jefe de la sinagoga, hinchado por su ciencia y orgulloso por su cargo, lo percibe con plena lucidez la sanada, porque su postración le ha abierto al Altísimo, del único que podía encontrar curación. La buena mujer logra encontrar una felicidad humana, que no había podido recibir de nadie. Sólo el enviado del Padre, el realizador de la misericordia divina, es capaz de concederle presente y futuro, así como suministrarle dicha humana.

Pero una vez más hay hombres duros, que se oponen a que Jesús obre el milagro en sábado. Les importa más atenerse a unos preceptos esclavizantes, que alegrarse por la extirpación del mal en una mujer buena, que está sufriendo lo indecible, pero que no deja de poner su esperanza en Dios. Quieren oponerse a que Jesús obre el bien en sábado y lo demás les trae sin cuidado. Pero Jesús les da la respuesta que se merece, por su insensibilidad, para ponerse en la situación de los que están aquejados por el dolor, después de llamarles «hipócritas».

De las instancias oficiales no puede esperar nada. Sólo rechazo y muestras de insensibilidad. Para colmo, el representante de la oficialidad legal se muestra como su verdadero adversario. Jesús, en cambio, se comporta con ella como el intérprete y ejecutor de la voluntad del Dios benevolente, que es misericordioso con toda clase de enfermos. En este caso concreto, ha estado atento a las necesidades de una mujer desamparada a causa de su larga y penosa enfermedad, que le impedía mirar al frente con la dignidad de las hijas de Abrahán. 


\subsubsection{La samaritana (Jn 4,1-42)}

El capítulo 4 del Cuarto Evangelio está centrado en el bellísimo encuentro entre Jesús y una mujer perteneciente a un pueblo mal visto por los judíos. Que Jesús entable un animado diálogo con una samaritana, divorciada nada menos que de cinco maridos y además hable solo con ella en un descampado, no dejaba de romper las reglas más elementales de la sociedad bien establecida y de los preceptos rabínicos, tan estrictos en aquella época. En ellos se criticaba, cuando no prohibía el trato directo con la mujer en público, mucho más con una pecadora perteneciente a un grupo heterodoxo.

Jesús no hace censuras severas al proceder de esta mujer en sus relaciones matrimoniales. Se limita a constatar la situación en que se encuentra. Ella misma puede sacar las conclusiones morales que se deducen de su proceder y el modo de atajar las posibles irregularidades existentes en su vida. Por eso, el encuentro de Jesús con la samaritana no tiene como finalidad el presentar su pasado pecador, aunque lo constate en el curso del diálogo.

Con su proceder Jesús rompe los convencionalismos sociales y morales, que no liberan sino que atenazan a las personas. Impresiona el respeto con que trata a esta mujer, reconociendo en ella la dignidad de quien toma muy en serio la propia existencia en comunión con sus paisanos, como podemos comprobar por el desarrollo posterior (4,28.39-42). Impresiona también cómo Jesús con gran mansedumbre va orientando a su interlocutora y dándole cumplida respuesta a sus planteamientos vitales, que son las eternas cuestiones religiosas de ayer, de hoy y de mañana. La primera se centra en el problema de la salvación, simbolizada en la imagen del «agua viva», tan querida para el evangelista; le segunda en la recta adoración de Dios y la tercera en la venida del Mesías. Por falta de espacio, dejamos a un lado otros aspectos, bien interesantes por cierto. Nos atenemos sólo a lo fundamental.

1. La primera cuestión planteada aborda de lleno el ser o no ser humano: el logro de la propia vida en su relación con Dios. Conviene notar de forma debida cómo se va desarrollando el diálogo. En un primer momento Jesús y la samaritana hablan en planos diferentes, no contrarios, pero sí bien distintos. El de Jesús se mueve en el ámbito espiritual; el de la samaritana, una persona práctica, en el material. Con gran celo y caridad pastoral Jesús logra que esa mujer de buena voluntad, con una vida turbia, vaya cambiando de modo de pensar, incluso de sentir y hablar. El agua para beber, 
del que habla Jesús aquí, no es el líquido elemento de la naturaleza, sino el don divino, la salvación final, la vida eterna que sólo Dios es capaz de otorgar a través de su Mesías. Se trata de un agua maravillosa, que calma la sed de felicidad, que anida en todo ser humano. Al final, la mujer se convence de que algo nuevo le está ofreciendo aquel judío misterioso y encantador, que puede cambiar de forma decisiva su vida. A través de lo material Jesús consigue abrirle a la gracia de la salvación. Lo que en definitiva importa no es tanto satisfacer las necesidades físicas, como lograr para siempre la vida, conseguida por medio de la revelación de Dios en su Cristo.

2. La segunda cuestión tiene que ver con la respuesta que el hombre está llamado a dar al Dios Salvador, tal como se verifica en el verdadero culto. En aquel momento, en que había dos templos, el de Jerusalén y el destruido sobre la falda del monte Garizim, el tema del culto constituía un problema candente. Jesús da una respuesta sorprendente que, actualizada en el momento actual, podía plantearse así: Habrá un momento en que no se tribute culto al Dios verdadero en los mencionados templos, hechos con piedras. El mismo Jesús, que se acredita como la manifestación plena de la divinidad, se convertirá en el último y definitivo Templo, en el que será posible el encuentro con Dios "en espíritu y verdad". Ese encuentro con el Dios vivo sólo será posible mediante la aceptación de la humanidad exaltada del Hijo de Dios (2,21s). Una frase es bien significativa: "Vosotros dais culto a uno que no conocéis; nosotros adoramos a uno que conocemos, porque la salvación viene de los judios" (v. 22). En ese "nosotros" están implicados no sólo la samaritana y los oyentes de la Palabra de la primera hora, también la comunidad del Discípulo Amado y los que ahora leemos el Evangelio.

3. La tercera cuestión toca el tema del Mesías, tan esperado en aquellos momentos. Ese Mesías de la expectación, a punto de llegar, es el mismo Jesús, que se autorrevela a la samaritana con la humildad de quien conoce la verdad y la expresa con convicción: "El Mesías soy yo, el mismo que está hablando contigo" (v. 26). ¡Qué reconfortante resulta este diálogo que el Cristo glorioso quiere tener también hoy con cada uno de nosotros, samaritanos necesitados de la verdadera salvación, del encuentro con Dios y su Mesías! Ojalá logremos sentir y vivir aquí y ahora lo que en su momento expresaron los samaritanos y con lo que termina el relato: "Ya no creemos por lo que tú nos dices, nosotros mismos le hemos oído y sabemos que él es de verdad el Salvador del mundo" $(4,42)$. 


\subsubsection{La adúltera (Jn 8,3-11)}

Estamos ante un diálogo de disputa entre Jesús y sus opositores, en el que aquél sale triunfante, poniéndose al lado, de modo incondicional y con una actitud misericordiosa, de una mujer pecadora, sorprendida en flagrante adulterio. Tanto la introducción, como las tres pequeñas partes en que se subdivide el texto, se comentan por sí solas. No necesitan especial consideración, para entender perfectamente lo que dicen.

Sí requieren de nosotros tener el corazón en su sitio, en orden a poder conectar con el modo de pensar, actuar y decidir del Nazareno, el sabio del Altísimo, que deja en mal lugar, el que en realidad les corresponde, a los que se creen muy listos y se acreditan como dechados de virtud. Pensar como Jesús, obrar conforme a su singular estilo de hacerlo, significa tanto como contar con el beneplácito divino y discernir de acuerdo con la sensibilidad humana, que proporcionan los dones del Espíritu.

Algo definitivo se nos muestra aquí en el comportamiento de Jesús, que encaja de lleno en su actividad pública en Palestina: la libertad con que se opuso a los desmanes de los que se tenían por buenos, sin serlo de verdad, la compasión con que siempre acogió a los pecadores y la delicadeza con que trató a las mujeres, sobre todo las que estaban en apuros (cf. Lc 7,3650). Jesús no niega la culpa, pero no hace de ella el contenido de su actuación. Bien al contrario, acoge a la pecadora con un amor efectivo, para que pueda superar su pecado y recuperar la dignidad perdida. «Mujer, ¿dónde están tus acusadores?; ¿ninguno te ha condenado?». Ella contestó: «Ninguno, Señor». Jesús dijo: «Tampoco yo te condeno. Anda, y en adelante no peques más».

Al final Jesús se queda solo con la acusada. Con su fina percepción de las situaciones San Agustín dictamina así: «Los que se quedaron fueron dos, lo digno de misericordia y la misericordia» Es decir, la adúltera, necesitada de misericordia, y el Señor, la Misericordia con mayúscula. Donde los hombres se muestran -o nos mostramos- duros e insensibles, allí Jesús descubre su misericordia entrañable, que refleja el proceder y comportamiento del Padre de los cielos. El amor está por encima de la intransigencia, supera el pecado y vence al castigo. Un mensaje que los creyentes de hoy necesitamos escuchar con atención y poner en práctica, testimoniándolo de modo vital ante los demás.

Igual que Jesús no condena, sino que salva, así la tarea de los creyentes en la sociedad actual consiste más que en tener palabras gruesas contra los demás, en ofrecer la salvación con nuestros hechos y gestos, si- 
guiendo al Maestro. Una oferta de salvación, que cuando se hace con su misma intención, comporta un cambio en la actuación del pecador, porque su vida se siente positivamente afectada, por la compasión y la misericordia, que se le ofrece con toda sinceridad.

\subsection{Signos de misericordia}

Como buen judío Jesús realizó un buen número de signos, que fueron más allá de sus palabras y de sus hechos. Lo decisivo del signo consiste en lo que deja traslucir, en su significación abierta y sugerente. En no pocos de ellos Jesús mostró una misericordia, que no deja de emocionar.

\subsubsection{La comensalía abierta (Mc 2,15-17par) en casa de Zaqueo (Lc 19,1-10)}

Uno de los hechos mejor testimoniados de la historia de Jesús tiene que ver con las comidas de amistad con toda clase de personas, que Jesús mantuvo a lo largo de su actuación pública. San Lucas se acredita como el evangelista que más presenta a Jesús, tanto el terreno como el resucitado, celebrando comidas de amistad (5,27-39; 7,36-50; 9,10-17; 10,38-42; 11,37-52; $14,1-24 ; 19,1-10 ; 22,7-38 ; 24,29-35.36-53)$, en no pocas ocasiones en comensalidad abierta. Come incluso con pecadores (Lc 15,2), de modo que sus enemigos encuentran en esta circunstancia una ocasión propicia para tildarlo de "comilón y borracho, amigo de publicanos y pecadores" $(\mathrm{Q} 7,35=$ Mt 11,19/ Lc 7,35).

Tienen especial significación los banquetes mantenidos, después del llamamiento de Leví-Mateo y de la conversión de Zaqueo. A este último queremos referirnos aquí. La escena acontece en Jericó, una población cercana a Jerusalén, bien glosada en la historia bíblica y de la que ya hemos hablado con ocasión del ciego Bartimeo. El viaje de Jesús está llegando a su fin y cada vez son más los que se arremolinan en su torno, cuando atraviesa la ciudad, acompañado de los suyos. Su paso no deja a nadie indiferente.

Después de algunas peripecias, Jesús se hace el encontradizo con un tal Zaqueo, nada menos que el jefe de los publicanos de la ciudad. Y surge como siempre la división ante el acercamiento de Jesús a personas de mala sociedad (Lc 5,28-32; 7,34.39; 15,1s). Todos los que lo rodean no entienden el trato deferente que dispensa a un reconocido pecador, odiado por su ra- 
piña. Para Zaqueo, en cambio, ese encuentro va a marcar para siempre el rumbo posterior de su vida. Este buen hombre, a pesar de su pésima fama, aprovecha con prontitud la oportunidad que se le brinda y sabe cambiar al instante de comportamiento.

Jesús expresa un deseo, que más que ruego suena a mandato: «hoy tengo que alojarme en tu casa». Conviene fijarse en el adverbio «hoy» (= on$\mu \varepsilon \rho o v)$ y los verbos griegos «tengo que alojarme» $(=\delta \varepsilon \iota \mu \varepsilon \mu \varepsilon \iota v \alpha \iota)$. Dei, como ya hemos resaltado en otras ocasiones $(13,33 ; 17,25 ; 24,26)$, tiene un significado muy preciso: «es necesario», es decir: «corresponde a la voluntad de Dios que hoy yo esté en tu casa». A través de la acción de Jesús, que se encuentra con aquel hombre pecador, el mismo Dios está mostrando su misericordia. Como transparencia eficaz de la misericordia divina, a través

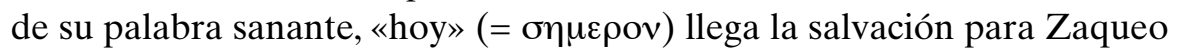
que, he aquí la primera sorpresa, la acoge alborozado, mostrando una gran alegría, ya que ha empezado a experimentar la salvación, tocado por la gracia.

Durante la correspondiente comida de amistad ambos entablan un diálogo cargado de contenido humano y moral, que transforma por completo a aquel hombre, curtido en las finanzas y en realidad poco dado a las emociones. Pero algo ha contemplado en el profeta de Nazaret, que le ha removido por dentro y le impulsa a llevar una nueva forma de vida. Al haberlo llamado por su nombre, Zaqueo ha caído en la cuenta que es Dios quien se acuerda y apiada de él por medio del que tiene sentado a su mesa. El pecador público adopta una actitud solemne y expresa ante el Señor el firme propósito de convertirse.

Está dispuesto a distribuir la mitad de sus bienes entre los pobres y se compromete a resarcir con creces a quienes haya perjudicado con el cobro abusivo de los impuestos, mostrando así una gran apertura de espíritu y una encomiable generosidad. Muestra una admirable disposición tanto interior como exterior y Jesús así lo reconoce públicamente. Sabe muy bien que su misión consiste en traer con su persona la salvación a los pecadores, de modo que sus palabras finales las hemos repetido con veneración los creyentes desde que fueron pronunciadas y escritas: «Hoy ha sido la salvación de esta casa; también éste es hijo de Abrahán. Porque el Hijo del Hombre ha venido a buscar y a salvar lo que estaba perdido».

Se trata del hoy de la salvación, que se realiza en el aquí y ahora de quien por la fe acepta la presencia sanante de Jesús. Lo que en su día se dijo de Dios y aparece consignado en la literatura sapiencial: «Corriges poco a poco a los que caen; a los que pecan les recuerdas su pecado, para que se con- 
viertan y crean en ti, Señor» (Sab 12,2), se hace realidad espléndida en el comportamiento del Nazareno.

Ese hoy sigue manteniendo su plena vigencia en todo tiempo y lugar. La tuvo en el momento de su nacimiento ( $\mathrm{Lc} 2,11)$ y muerte en la cruz (Lc 23,43); y encuentra en el presente actualizado el mismo eco de entonces. Importa sobre todo comprobar cómo la misericordia de Jesús ha conseguido el cambio por completo de un publicano, que ha devuelto lo robado y se lo ha dado a los pobres.

\subsubsection{Lamentación por Jerusalén (Mt 23,37s; Lc 19,41-44)}

Jesús no cesó de llamar a la conversión a su pueblo, con el que se sentía tan íntimamente unido. Sus invitaciones a acoger el reinado de Dios con las actitudes requeridas resonaron en todas las regiones de Palestina, empezando por la querida Galilea. Sin embargo muchos de los suyos, la inmensa mayoría, hicieron oídos sordos a sus llamamientos, cargados de especial emoción y advertencia. Hasta los últimos momentos se dirigió a sus compatriotas, para que dejaran reinar a Dios en sus vidas y se abrieran a su mensaje de amor.

San Mateo y San Lucas nos han dejado dos impresionantes testimonios, anclados sin duda en el Jesús terreno y dirigidos a los habitantes de Jerusalén en la última etapa de su andadura histórica:

«Jerusalén, Jerusalén, que matas a los profetas y apedreas a quienes te han sido enviados, cuántas veces intenté reunir a tus hijos, como la gallina reúne a los polluelos bajo sus alas, y no habéis querido. Pues bien, vuestra casa va a quedar desierta» (Mt 23,37s).

Pocas palabras tan sentidas y repletas de atención, como este impresionante dicho, lleno de misericordia y conmoción. El doble vocativo no deja de impresionarnos. El bello símil que emplea ofrece una gran ternura y bondad, pero no alcanza su objetivo. Jesús solicita repetidamente de los jerosolimitanos la conversión a los planes divinos y percibe con especial dolor que su intento de reunir a su pueblo en una familia de hijos y hermanos, para presentársela a su Padre como ofrenda agradable ante sus ojos, acabará con el más rotundo de los fracasos. Como a los antiguos profetas de otro tiempo, el pueblo responde con flagrante desobediencia. De ahí que les ad- 
vierta las consecuencias desastrosas, que va a tener para su vida este rechazo frontal inmerecido. Toda la situación le duele especialmente.

San Lucas nos dice que incluso llora, cuando Jerusalén ignora su visita: «Al acercarse y ver la ciudad, Jesús lloró sobre ella, mientras decía: "iSi reconocieras tú también en este día lo que conduce a la paz! Pero ahora está escondido a tus ojos. Pues vendrán días sobre ti en que tus enemigos te rodearán de trincheras, te sitiarán, apretarán el cerco de todos los lados, te arrasarán con tus hijos dentro, y no dejarán piedra sobre piedra" (Lc 19,41-44).

Jesús vierte lágrimas ante Jerusalén, como lo había hecho también en la muerte de su amigo Lázaro (Jn 11,35), a quien tanto quería. Son las dos únicas veces, en las que se dice de manera explícita que Jesús lloró. Se trata de un lamento verdadero, porque una tragedia de grandes dimensiones se avecina. Su misión ya no tiene posibilidades de intervenir en la situación, sino tan solo constatar su fracaso y al mismo tiempo comunicar el juicio de Dios. Ya que el pueblo está obcecado y no quiere reconocer el don y el proyecto divino, sus enemigos van a proceder con un rigor horrible contra la ciudad.

Cuando la misericordia no alcanza su objetivo, Jesús llora desconsoladamente, empleando un signo, que llega a lo más íntimo y que ya habían usado los profetas de la Primera Alianza. Más que en ningún otro lugar el evangelista sitúa aquí a Jesús en la línea de los grandes carismáticos de Israel. Todo un signo de amor por su parte y de rechazo por parte de los incrédulos jerosolimitanos, que nos están dispuestos a acoger su mensaje y a obrar en consecuencia. Se portarán con él como auténticos traidores. Le acogerán con aclamaciones en un primer momento, pero días después lo llevarán a la cruz.

\subsubsection{El lavatorio de los pies (Jn 13,1-20)}

En la noche de la pasión Jesús lavó los pies a sus discípulos. Se trata de un signo profético, basado en un hecho real, verdadero, que ofrece una gran significación de misericordia en la intencionalidad del Jesús terreno. Con él reclama de Pedro, de todos los discípulos y de los lectores del Evangelio que se dejen conducir por sus palabras, aceptando el simbolismo inherente a tal gesto, cargado de un gran amor y de un cariño sin límites. Lo que hace grande al discípulo es la entrega y el servicio en favor de los demás, como le hizo grande a su Señor y Maestro. Aquí concentra toda su vida de entrega a los demás, de amor y de cariño. El gesto quedará bien grabado en la me- 
moria de los discípulos, llamados tanto a la contemplación como a la acción. Toda la existencia de Jesús fue en realidad una pro-existencia, una vida desgastada por los demás de acuerdo con los designios divinos. Esta pro-existencia se resume y plenifica en ese lavatorio. En realidad estamos ante un signo «creativo, provocativo, con gran poder significante y que invita a la conversión», como quiero mostrar ahora.

1. En primer lugar el lavatorio brilla con luz propia como un signo creativo de primera magnitud. Introduce un nuevo rostro de Dios y la visión de un hombre nuevo, dotado de un corazón renovado por la gracia del Espíritu. Efectivamente, con su gesto, Jesús efectúa una inversión de la concepción tradicional de Dios y, en consecuencia, de su relación con el hombre y de los hombres entre sí. El Padre, que no ejerce el dominio, sino que comunica vida y amor de misericordia, no legitima ningún poder ni dominio de unos sobre otros. En Jesús Dios ha recobrado su verdadero rostro, deformado de mil maneras por el hombre. Éste había proyectado en él sus ambiciones, miedos, intereses y crueldades. Jesús muestra que Dios es Padre y que se compromete con su obra, la creación, para llevarla a plenitud. Y en esa creación sobresale de modo especial el hombre, a quien Jesús reta para que actúe como su Maestro actuó. En ello se juega la persona más de lo que se puede pensar a simple vista.

También nos muestra que los hombres entre sí son hermanos, a quienes sólo se les contempla adecuadamente, cuando se adopta la posición del servidor. Lo que importa en la persona no es el sobresalir, el mostrar los ademanes del poderoso, que se realiza situándose por encima de los demás y ejerciendo ante ellos su poder y en no pocas ocasiones su violencia; más bien el ser ó no ser humano, que se proyecta hacia un futuro prometedor, está en el servir, en el darse, asumiendo la actitud del que se entrega, incluso aunque no le den nada a cambio. Así obra Jesús, porque así ha contemplado el obrar al Padre. Y así estamos llamados a obrar los discípulos, que queremos permanecer en el amor de nuestro Maestro y Señor (Jn 15, 4-17).

El fundamento de la comunidad radica en la igualdad y libertad de los hijos de Dios, reunidos de la dispersión por la entrega de Jesús a la muerte $(11,52)$. La verdadera grandeza del discípulo del Maestro no está en el honor humano $(5,41)$, sino el que procede del Padre $(5,44)$, el que busca parecerse a Él e imitarlo, tal como nos lo ha mostrado su Hijo. No son los gestos espectaculares y llamativos los más efectivos, tampoco los que se imponen por la fuerza, sino los provenientes de la entrega generosa a los demás, asumiendo voluntariamente el dolor redentivo; son los gestos del "perdedor" los que tienen el poder de transformar los corazones y renovar 
los comportamientos, siempre fijando la mirada en la actuación y en las palabras del Señor y Maestro. Si el señor-maestro sirve, entonces se otorga a los discípulos, porque son servidos, una dignidad similar a la del señor-maestro.

Pero, cuidado, el gesto realizado por Jesús la noche de la Pasión no está llamada a ser repetido miméticamente sin más, sino a ser recreado y hacerlo testimonio vivo en el tiempo que nos toca vivir, cuando existe todo un estallido de placer replegado en sí mismo, que crea egoístas, impide el reconocer a los demás, abrirse a sus necesidades y compadecerse de su dolor con una lucha activa contra el mal.

Importa sobremanera que la persona entera del creyente, sus afectos y sentimientos, sus ideas y pensamientos entren progresivamente en el misterio del Hijo, conformándose en el corazón y en la mente, en las inclinaciones y atracciones con su imagen, tanto a nivel consciente como inconsciente, para conseguir la identificación profunda con Cristo y la unificación interior de todo su ser y quehacer.

2. En segundo lugar estamos ante un gesto provocativo. El signo se presenta desafiante en extremo, lleno de fuerza y vigor, sobre todo para los que han hecho una opción por Jesús. Desestabiliza nuestro modo de pensar y actuar, tan marcadas por la mirada a uno mismo, por buscar y pretender alcanzar siempre ventajas propias. Desde luego es una Buena Noticia en sumo grado, para aquellos que han escogido vivir desde la gratuidad, que nos proporciona la persona, vida, obra y destino de Jesús. Cada una de las acciones, llevadas a cabo por el Maestro en el lavatorio, impresiona nuestra alma, sus palabras penetrantes hacen tambalear nuestras opciones y su comportamiento humilde nos interpela de muy diversas maneras.

Aquí se nos pide nada menos que salir con actitudes misericordiosas de nuestras pequeñas ó grandes seguridades, hacer la travesía del desierto en nuestros propios valores y llegar a la tierra de promisión, que son los otros, estando dispuestos incluso a asumir «lo más bajo» de ellos. Es en ese descenso a lo más escondido de la humanidad de nuestros hermanos, donde se nos brinda el logro de la existencia colmada. Cierto, dado el grado de egoísmo que nos caracteriza como fruto del pecado, esta salida hacia los demás y este descenso a su dignidad, no puede hacerse sin la gracia divina y sin la asistencia del Espíritu.

Pero necesita también el valor y arrojo con la docilidad de quien sabe que lo que el Maestro le indica conduce hacia la verdadera vida y la consecución de la felicidad, por paradójico que parezca. Sólo saliendo de sí mismo, en un acto de osada decisión y arriesgada valentía, y abriéndose in- 
condicionalmente al otro sin esperar nada a cambio, el discípulo está capacitado para experimentar la alegría de la salvación, que le ofrece su Cristo en este gesto provocador, pero ¡también salvador!

Lo que conlleva, al mismo tiempo, aceptar y amar al prójimo por lo que es, más allá de sus grandezas y miserias, por encima de lo que pueda darnos, ya que sólo existe un auténtico camino de salvación: el que no busca servirse de los demás, sino servirles, si es preciso hasta la extenuación, hasta el último suspiro, como hizo Jesús. El que no se sitúa por encima de los otros, sino que asume la actitud humilde y eficaz del perdedor, a los ojos del mundo, aunque en realidad es el ganador a los ojos de Dios, como aconteció con el Crucificado Resucitado.

3. En tercer lugar es un gesto con gran poder significante. Puede ser que para nosotros el signo profético del lavatorio haya perdido mucha de la fuerza de su poder simbólico, porque vivimos en una época en que se ha superado la vieja sociedad esclavista, donde encajaba perfectamente la genuina circunstancia originante del signo. Situado en su época y en su contexto vital, el lavatorio representa un signo bien elocuente para expresar una nueva concepción tanto divina como humana, que nos puede hacer pensar mucho y ayudar a cambiar la mentalidad y a transformar los comportamientos.

Jesús se identifica con aquellos, que no contaban nada, que eran despreciados y se les obligaba a realizar un trabajo humillante, una labor sucia, cargada de degradación y hasta de desprecio. Nada menos que el Señor ocupa el lugar del esclavo, del despreciado en su trabajo. El Maestro se rebaja hasta límites insospechados. No cabe duda que el comportamiento de Jesús no puede ser entendido sin un cambio radical de conciencia y un reciclaje en la comprensión: el amor, que se verifica en la propia humillación y en la disposición interior de ser y obrar a favor de los otros. Amar significa ayudar al otro para su propia vida, su libertad, autonomía y capacidad vital; proporcionarle el espacio vital humano que necesita.

Con este gesto Jesús se muestra como el revelador del Padre, que está siempre cercano al hombre y no tiene reparo, a pesar del pecado humano, en condescender con él sin agotarse en sus intenciones y está dispuesto incluso a rebajarse allí donde ningún humano estaría dispuesto a hacerlo. Según Juan, Jesús ha dado un contenido y sello totalmente nuevos a la idea de Dios, en la que entraban desde antiguo los conceptos de omnipotencia y soberanía, por cuanto muestra que a Dios se le encuentra allí donde se renuncia a todo poder y dominio y se está abierto a los demás. ¡Cuándo nos convenceremos que Dios en Cristo no impone, sino propone, no adopta la 
forma del prepotente sino del humilde, que eleva con la garantía de su amor!

4. Por último el gesto contiene una llamada a la conversión. El gesto de Jesús exige entonces un cambio radical en nuestra vida de discípulos, una transformación de los ideales y una renovación sincera de las prioridades, que dan sentido a nuestra existencia en la comunidad de la Iglesia, de manera que orientemos nuestro vivir en consonancia con la actualización del bautismo y con la vivencia de la Eucaristía, como sacramento del amor filial y fraterno.

A los ojos divinos el mayor no es el que tiene riquezas, ciencia ó poder, sino el que se pone a disposición de los demás a fondo perdido, no considerando su propia ventaja, ni la adquisición de beneficios propios, sino buscando el provecho de los otros, aunque sea a costa de su rebajamiento y humillación. Así nos lo mostró el Cristo del lavatorio, que al mismo tiempo es el Kyrios glorioso de la Pascua.

Dichoso en esta vida y en la otra no es el que ríe estrepitosamente, el que busca el placer a toda costa, el que persigue las apariencias de este mundo, el que amontona riquezas con la avidez del insaciable, sino el que confía en las palabras de Jesús, su Mesías, Maestro y Señor, y adecua su comportamiento con el suyo, desgastando su vida por imitar su ilimitado amor, trasunto del amor del Padre.

Así se entiende mucho mejor el testamento de Jesús la noche en que iba a ser entregado, cuando nos entregó su cuerpo para siempre y derramó su sangre por nosotros. Ese testamento puede resumirse en estas palabras: "Como el Padre me ama a mí, así os amo yo a vosotros. Permaneced en mi amor. Pero sólo permaneceréis en mi amor, si obedecéis mis mandamientos, lo mismo que yo he observado los mandamientos de mi Padre y permanezco en su amor. Os he dicho esto para que participéis en mi gozo, y vuestro gozo sea completo" (Jn 15, 9-11).

El gesto del lavatorio no es otra cosa que la puesta en la práctica de estos deseos y recomendaciones de Jesús, en el preciso momento en que iba a entregar su vida por nosotros y a convertirse en "causa de nuestra alegría". La misericordia de Jesús, convertida en comunión entrañable con sus discípulos, se vuelve servicio incondicional en beneficio de los suyos.

La misericordia no puede quedarse tan sólo en objeto de conocimiento y especulación por bien intencionada que sea, sino en parte práctica de nuestra vida de cada día. 
«La misericordia de Dios es muy concreta

y todos estamos llamados a experimentarla en primera persona».

(Papa Francisco)

\section{La Pascua de la misericordia}

Tres acontecimientos de primer orden integramos aquí para la adecuada valoración de la misericordia en la historia de Jesús: la institución de la eucaristía, la muerte en la cruz y las apariciones. Los tres hechos de valencia suprema se presentan tan implicados entre sí, que forman la única realidad de la Pascua del crucificado Resucitado.

\subsection{La Institución de la Eucaristía (Mc 14,22-25par)}

La cena pascual de Jesús con sus íntimos constituye la última y más importante de las comidas mantenidas por Jesús a lo largo de su actuación pública y puede considerarse como el pórtico de entrada en el acontecimiento de la Pascua. En ella se encuentran sus más allegados, el grupo de los Doce. No se señala que hubiera otras personas, de modo que no se menciona a mujeres, ni tampoco a otros discípulos o habitantes de la casa donde se celebró, lo que no excluye que pudieran encontrarse otros invitados. Con todo en la tradición sinóptica los que hablan pertenecen siempre al grupo de los Doce.

Importa resaltar que en esta comida de amistad, desarrollada en un clima de intimidad como ninguna otra, llega a su punto culminante la proexistencia de Jesús, donde más se expresa su amor y su misericordia entrañable a los suyos y en éstos a la humanidad entera. Aquí la entrega de Jesús, su amor misericordioso ofrece rasgos de emocionante originalidad.

El anfitrión, que se identifica con Jesús de Nazaret, se ofrece a los suyos de una manera tan intensa y real, que se convierte en un cuerpo entregado y en una sangre derramada por todos nosotros: para ti y para mí, para la humanidad entera. El amor de misericordia alcanza las últimas consecuencias que suponen una donación total y para siempre. Total, porque no se puede pedir más. Para siempre, porque su donación tendrá una actualidad, que traspasa y supera el tiempo. Permanecerá con nosotros como el que se da sin retener nada de lo suyo, ni su cuerpo, ni su vida. Ofrece cuanto es, 
para entrar en una comunión íntima con los que quieren permanecer en relación con su ser expropiado.

San Marcos ha reproducido la realidad histórica de las palabras y gestos de Jesús en el núcleo de esta cena con la mayor fiabilidad histórica. Lo ha señalado con brevedad, pero con una contundencia, que conviene desentrañar como se debe. En el contexto de la cena ofrece unos gestos de Jesús, acompañados de unas palabras, cuya significación precisa la más exacta aclaración.

Pero antes presentemos el relato: "Mientras comían, tomó pan y, pronunciando la bendición, lo partió y se lo dio diciendo: "Tomad, esto es mi cuerpo”. Después tomó el cáliz, pronunció la acción de gracias, se lo dio y todos bebieron. Y les dijo: "Esta es mi sangre de la alianza, que es derramada por muchos. En verdad os digo que no volveré a beber del fruto de la vid hasta el día que beba el vino nuevo en el reino de Dios”»(Mc 14,22-25 par.).

Todo ocurre en el marco de una comida festiva donde las haya. Jesús hace gestos sobre el pan: lo toma, lo bendice, lo parte y lo da. Y dice unas palabras sobre el pan con un requerimiento: Tomad y unas palabras de interpretación: Esto es mi cuerpo. Conviene detenerse en estas cuatro palabras, cinco en griego: $\tau o v \tau o ~ \varepsilon \sigma \tau \iota v \tau o ~ \sigma \omega \mu \alpha \mu \nu v$. Jesús está indicando el verdadero contenido del pan: esto soy yo mismo. En este pan me entrego incondicionalmente.

El hondo sentido de estas palabras no dejan lugar a dudas: Este pan es ahora el mismo cuerpo de Jesús de Nazaret. Su persona está de tal modo comprometida en ese pequeño trozo de alimento, que misteriosa pero realmente está contenida en él. $\Sigma \omega \mu \alpha$, cuerpo no es sino la expresión externa y el signo de su persona misma. Ese trozo de pan contiene la realidad personal de Jesús, es él mismo en persona. Su darse es absoluto, sin reservarse nada para sí mismo. ¿Puede encontrarse un amor oblativo, una misericordia mayor?

También hace gestos sobre el cáliz con vino. Lo toma, lo bendice, lo comparte. Se informa que todos bebieron de él. Vuelven a seguir palabras de interpretación: Esta es mi sangre de la alianza, que es derramada por mu-

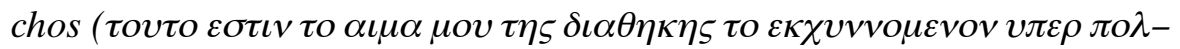
$\lambda \varpi v)$. Jesús se está refiriendo al vino, que ofrece a los Doce en el cáliz. Ese vino se identifica con él mismo, que va a ser entregado a la muerte para salvación de los humanos. Ese vino se ha trasformado en una sangre derramada en beneficio de «muchos», para bien de la humanidad entera. Diferenciamos las palabras de Jesús: 
«Esta es mi sangre», evidencia un paralelismo total con «esto es mi cuerpo». A $\sigma \omega \mu \alpha$ se contrapone $\alpha \mu \mu \alpha$, sangre. La vitalidad del cuerpo se presencializa a través de la sangre, conforme la visión de aquella época. La sangre posibilita que el cuerpo viva. En la comprensión antropológica semita existe complementación entre el cuerpo y la sangre. Teniendo en cuenta estas apreciaciones, las palabras de Jesús tienen este sentido: Ese vino, contenido en el cáliz, es ahora la sangre de Jesús de Nazaret. Su vida entera, entregada por los hombres, está comprometida en ella.

La expresión «sangre de la alianza» hace una clara referencia a Ex 24,8: «Entonces Moisés tomó la sangre y roció al pueblo, diciendo: "Esta es la sangre de la alianza que el Señor ha concertado con vosotros, de acuerdo con todas estas palabras"». El gran legislador judío, intermediario entre Dios y su pueblo, corrobora el pacto de amistad estipulado entre Dios y los israelitas mediante el hondo símbolo de la aspersión de la sangre. La sangre de Jesucristo abre una nueva alianza en la historia de la humanidad. Jesús se alza como el nuevo Moisés, que inaugura otra alianza plenificada, que será definitiva. Su propia sangre, derramada en la cruz, sirve de broche de oro a ese nuevo pacto, cerrado entre Dios y los hombres. Por eso esa sangre bendita es derramada por muchos.

Esta última expresión hace referencia al carácter expiatorio de la muerte de Jesús. Los «muchos», sobre los que va a ser derramada esa sangre, están significando a la totalidad de los israelitas, ese pueblo pecador, que repetidamente rompió la alianza sinaítica. En los «muchos» está incluida también la humanidad entera, en cuanto está infectada por el pecado y encadenada a su servidumbre. La fuerza salvadora y vivificadora de la sangre de Jesús, derramada sobre el madero de la cruz, está destinada al Israel pecador y en él a todos los hombres.

Ese vino de la fiesta, que los Doce están tomando, no constituye tan sólo un símbolo de la sangre de Jesús, sino en él está verdaderamente su propia sangre, que está empezando a surtir sus efectos salvadores en un grupo de hombres concretos, que participan también de la condición pecadora. Sangre derramada por muchos está haciendo referencia libre a Is 53,12, que tiene como sujeto al Siervo de Yahvé. Jesús se identifica así con el Siervo de Yahvé doliente, que «llevó el pecado de muchos e intercedió por los rebeldes».

Jesús se entiende a sí mismo como el Siervo de Yahvé del Deuteroisaías, que con su misericordia entrañable obra en nombre de su Padre como mediador de la salvación y realiza una nueva alianza, sellada con su sangre. La bondad del Hijo del Hombre por excelencia, propia del que ha hecho 
de la misericordia el principio de su obrar, se traduce sobre todo en su proexistencia practicada en lo cotidiano, que concluye con su entrega eucarística y con su trágica muerte en la cruz, que a continuación vamos a comentar.

En pocas palabras finales: La cena de la Pascua, la Eucaristía, se ha convertido desde entonces para los creyentes en el hogar por excelencia de la misericordia del Padre, donde el Señor Jesús se nos sigue entregando sin reservas, sigue perdonándonos nuestras infidelidades y nos sigue mostrando su cariño y compasión. Nos bendice y alienta, nos abre al Espíritu y nos consuela con las palabras del Evangelio. Estamos ante el excepcional banquete de la misericordia, en el que el anfitrión se da a sí mismo en comunión plena con sus invitados. No hay nada más verdadero y bello que la misericordia entrañable que resplandece en la Eucaristía y se transmite en su celebración.

\subsection{La muerte en la Cruz (Mc 15,21-41)}

Muchos aspectos podemos considerar en torno a la muerte de Jesús. Me centro tan solo en la presentación de la crucifixión en el relato más antiguo sobre este acontecimiento y me limito a resaltar la inmensa misericordia del Crucificado en el momento de entregar la vida. La crucifixión constituye la escena cumbre y más significativa del Evangelio de San Marcos, el primero redactado de los cuatro evangelios.

Si toda la obra marquina está orientada hacia la Historia de la Pasión, el documento más importante que el evangelista emplea en su escrito, aquélla está orientada hacia la muerte de Jesús en la cruz de acuerdo con las Escrituras. Hay que conceder una importancia suma a esta escena impresionante, que como ninguna ha influido de modo decisivo en la teología y en la espiritualidad del cristianismo. De entrada hacemos estas tres constataciones.

a) El hecho más fehaciente de la historia de Jesús, testimoniado incluso por historiadores romanos de la época, está en la muerte de Jesús en el suplicio tremendo de la cruz. Procedente de las crueles costumbres persas, los romanos reservaron este suplicio para sus peores y más peligrosos enemigos políticos. El Nazareno fue considerado como uno de ellos por los dominadores de una época agitada, de notables cambios sociales, convulsión política y efervescencia religiosa. 
b) Sin la muerte en la cruz no se entendería el ser y actuar de Jesús, de modo que quedaría sin significado lo nuclear de la historia de Jesús, que tiene en la misericordia el centro de su ser y actuar. La cruz resume y hasta plenifica, como ningún otro hecho jesuádico, el discurrir terreno de Jesús, como hombre dotado de una bondad inmensa. Su existencia expropiada, volcada en beneficio de los demás de acuerdo con los designios de su $A b b a$, llegó a su máximo anonadamiento en su muerte horrenda. En ella el vaciamiento existencial más impresionante, que ha conocido hasta la fecha la historia de la humanidad, alcanza la máxima expresión. Por caminos insospechados llega a abarcar las dimensiones fundamentales del hombre y los valores por los que merece la pena vivir: el amor y la esperanza, la unidad y la igualdad, la justicia y la paz, la amistad y la fraternidad, hasta el futuro de la felicidad humana están presentes y operantes en este acontecimiento salvador.

c) Todos los aspectos centrales de la teología, la espiritualidad y la religiosidad popular brotan de esa muerte cierta y confluyen en su decisiva significación. La verdad de la Trinidad resplandece aquí como en ninguna otra parte. La aparente derrota de la cruz contiene en sí misma ya el triunfo de la resurrección. En la sencilla, pero contundente narración marquina se encuentran los caminos, que conducen al Dios vivo y verdadero en su infinita misericordia y al hombre auténtico, que quiere lograr la propia existencia y llegar a la plenitud. Esta escena ha sido decisiva también para el arte y la literatura.

\subsubsection{La intencionalidad de la escena}

Ninguna escena ha dispuesto San Marcos en su obra con tanta intencionalidad como la referente a la crucifixión. Si todo el evangelio está orientado hacia la historia de la pasión, toda la historia de la pasión está orientada hacia la cruz. La muerte de Jesús con sus secuelas constituye, por lo tanto, el centro del núcleo de todo el escrito. Conviene ahondar en su significado para dar con la clave básica, que nos ayude a ahondar en el significado de la escena marquina. Una clave que tiene que ver con su misericordia entrañable.

El evangelista está ciertamente interesado en presentar el escarnio de que fue objeto Jesús por parte de sus enemigos. Pero sobre todo le interesa 
resaltar las palabras finales del Crucificado, que muere en el madero de la cruz de modo horrendo, experimentando el abandonado de todos, incluso de su Abba, Padre, llamado aquí Eloí: «Jesús clamó con voz potente: Eloí Eloí, lemá sabactaní (que significa "Dios mío, Dios mío, ¿Por qué me has abandonado?"» (Mc 15,34).

El Hijo de Dios, que había entregado su vida por los demás, muere en el mayor de los desamparos, experimentando el hundimiento total de su existencia. Su amor servicial no sólo le lleva al intenso dolor, también a la más absoluta de las soledades. El amor que es apertura y reconocimiento, respuesta y agradecimiento se muestra aquí como desamparo sin paliativos, truncamiento de cualquier relación gratificante. Jesús cae en una soledad total, porque todos le cierran las puertas de la acogida. Muere de verdad, en el sentido más pleno de la palabra. Pero en esa muerte prende la vida (Jn 12, 24: «En verdad, en verdad os digo: si el grano de trigo no cae en tierra y muere, queda infecundo; pero si muere, da mucho fruto»). En esa muerte resplandece la mayor de las misericordias.

El fruto ya aparece incluso en el relato. Un fruto cósmico y un fruto personal. El primero se produce en el ámbito del templo: «el velo del templo se rasgó en dos, de arriba abajo» $(15,38)$. El segundo sucede en el corazón de un hombre de buena voluntad, que al verlo expirar no puede por menos de exclamar: «Verdaderamente este hombre era el Hijo de Dios» $(15,39)$. Acaba lo viejo y viene de nuevo; con el Crucificado todo se convierte en nuevo, viviente, porque su morir está orientado hacia el amor que todo lo regenera.

La narración, tal como salió de la pluma del evangelista, no está expuesta sin más en un simple afán de recoger lo sucedido una vez. Tiene una clara intencionalidad teológica, que intentaremos mostrar lo más claramente posible. Baste ahora recordar que une una serie de elementos, que se complementan mutuamente: tradición y redacción, intencionalidad teológica y significación cristológica. En el relato se ofrece una visión religiosa de primer orden: nos habla de Dios Padre y sobre todo de su Cristo e Hijo. Hace referencia al terrible pecado humano y de la respuesta salvadora de lo alto. En la narración está contenida en miniatura toda una historia de la salvación, como tendremos ocasión de mostrarlo paso a paso.

Marcos quiere que la narración hable por sí misma con un lenguaje sencillo, pero cargado de significatividad y responsabilidad. No se pueden observar los hechos mostrados, sin sentirse afectados por ellos e implicados en su desenlace. Deja traslucir dos posturas antagónicas, que en su contraposición recogen patrones representativos ante la persona del ajusticiado. 
Los que rechazan a Jesús y consideran su muerte como maldita y los que sorprendidos y hasta agradecidos aceptan esa muerte horrenda como un acontecimiento salvador, que tiene que ver con el presente y futuro de la humanidad, ya que en ella se juega mucho. Su amor al final no permanece oculto. Irradia hasta el centurión, las mujeres, que observan a lo lejos y el propio evangelista que se oculta detrás del relato. La fe de éstos contrasta con la incredulidad de aquéllos. Si en algún lugar prueba Jesús su filiación divina es precisamente en la tragedia de la cruz, en la asunción de una muerte horrible y en el derramamiento de una sangre «por muchos» $(14,24)$.

Se trata de una escena decisiva y compleja a la vez. Decisiva sí, por la importancia excepcional que tiene en la historia de la pasión y en el conjunto del evangelio; compleja también, porque hasta ahora no se ha logrado unanimidad en la exégesis en la valoración global de los hechos. Los análisis son múltiples y con relativa frecuencia bien orientados. Pero en esta narración confluyen tradiciones vivas, provenientes de diferentes sensibilidades religiosas, que no son fáciles de detectar y que conviene tener en cuenta.

\subsubsection{La revelación definitiva de la misericordia de Dios}

Todo el Evangelio y en él toda la historia de la pasión y en ésta la perícopa objeto de nuestro estudio, están orientados hacia la muerte de Jesús en la cruz. En la muerte de Jesús se ha producido un final y se inaugura algo radicalmente nuevo. Lo más sagrado del templo ha perdido vigencia, porque ahora irrumpe la salvación definitiva de Dios, realizada en la entrega última del Crucificado. Nuevos valores suceden a los viejos planteamientos.

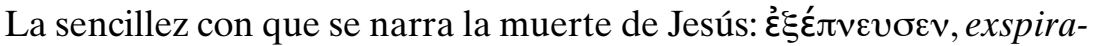
vit, expiró, en realidad está indicando la eficacia salvadora de esa muerte bendita, que produce vida para siempre. Ya no se requieren las palabras, se necesita un corazón bien dispuesto para acogerla, como hizo el centurión romano, como han hecho los cristianos de todo los tiempos.

Todos los indicios descriptivos nos llevan a considerar la muerte de Jesús como un acontecimiento escatológico. Con ella irrumpe un tiempo nuevo, el de la salvación definitiva, que no tiene marcha atrás. En el silencio de Dios se cumple la promesa de que el hombre está llamado a la vida. Algo nuevo tiene su comienzo, de manera que se convierte en la revelación definitiva de la misericordia infinita de la Trinidad. Si toda la historia de Je- 
sús encuentra su sentido bajo el signo de la novedad, su muerte lo está de una manera muy especial. En el silencio divino en torno al Abandonado la omnipotencia del Todopoderoso hace surgir una nueva creación.

Expira después de dar un fuerte grito, $(15,37)$ como el cordero llevado al matadero de Is 53. «El que no cometió pecado, ni en su boca se halló engaño; el que injuriado no devolvía las injurias, ni atormentado amenazaba, sino que confiaba en Dios que juzga con justicia» (1 Pe 2,22s), soportó nuestros pecados sobre el madero de la cruz, hasta el punto que, muertos al pecado, podamos vivir y alcanzar la salvación (Rom 6,1ss). Los que no conocíamos la misericordia, ahora la hemos alcanzado en demasía (1 Pe 2,10). Ese es el hondo significado, que se deduce de la cristología narrativa de la acción de Jesús, presentada por San Pedro en este memorable instante.

\subsubsection{La significación de la muerte de Jesús, colmada de misericordia}

La muerte viene precedida por unas desasosegadas palabras, tomadas del inicio del Sal 22, que Jesús dirige a Dios en la situación más límite de su existencia. Aquí suenan como el revés de las expresadas en su día por el salmista. Son las únicas palabras que Jesús pronuncia en la cruz, según San Marcos. Otros han hablado para burlarse de su estado, él sólo puede expresar su angustia ante Aquel que puede escucharle, aunque le sienta lejos. Lucas $(23,34.43)$ y Juan $(19,26 s .28)$, que han ahondado en la significación del acontecimiento, aportan otras palabras, que en el momento de morir se convierten en auténtica oración de conformidad con la voluntad del Padre (Lc 23,46) y con el cumplimiento de su misión (Jn 19,30).

Palabras fuertes y estremecedoras las transmitidas por la más antigua historia de la pasión, que constituyen todo un grito de congoja extrema en el momento final. De hecho el grito de abandono de Jesús constituye la expresión más nítida de una angustia sin límites en el abismo de su soledad; pero también muestra la entrega de una misericordia sin límites, que ha hecho de la asunción del dolor propio el principio de su actuación. Privado de todo sustento, Jesús muere sintiendo incluso el abandono de su Padre, con quien había estado plenamente identificado durante su anuncio del reino y con quien había mantenido una singular comunión íntima a lo largo de su vida.

Ahora no siente su cercanía, sino su abandono, incluso su rechazo. Sólo el hecho real de que «Él llevó nuestros pecados en su cuerpo hasta el leño, para que, muertos a los pecados, vivamos para la justicia. Con sus heridas 
fuisteis curados», como apuntó certeramente 1 Pe 2,24, puede explicar un final tan trágico y en gran medida tan escandaloso, pero tan lleno de solidaridad misericordiosa con los humanos. Su solidaridad con los hombres llegó hasta el final, hasta el escándalo de cargar sobre sus hombros con todo el pecado de la humanidad y asumir nuestro propio destino. Ese pecado que supone separación de Dios, la sintió Jesús cuando murió «para el perdón de los pecados» (Mt 26,28), como expresa Mateo en las palabras que Jesús dice sobre la copa de vino, convertida en su sangre, «derramada por muchos» (Mc 14,24).

El justo por excelencia muere como muere por amor a los injustos, para que tengamos vida, expresando con la humanidad caída una misericordia que cuanto más se muestra más se admira. La fuerza destructora del pecado es tal que lleva a la muerte al Justo con mayúscula, al cargar sobre sus hombros los pecados humanos. Jesús acepta una muerte que no es la suya, pero que constituye el fruto sazonado de un gran amor, que tendrá repercusiones imperecederas para la Iglesia y para la humanidad entera. Nunca la misericordia había llegado a cuotas tan altas.

\subsubsection{Con Dios, pero sin Dios}

Sobre la muerte de Jesús D. Bonhoeffer ha escrito esta admirable reflexión: Jesús muere con Dios, pero sin Dios. Ambas afirmaciones, que parecen contradictorias, son verdaderas y merecen una explicación al tener que ser mantenidas juntas. Efectivamente, muere con Dios, porque nada resquebraja su confianza en su Abba. Sigue poniendo la esperanza en quien es todo en su vida que acaba. Se cumple lo que más tarde formulará Pablo de Tarso, hablando del padre del pueblo judío: «Apoyado en la esperanza, creyó contra toda esperanza» (Rom 4,18). Vivió hasta las últimas consecuencias las exigencias del amor. Es precisamente en esa muerte horrenda, que nadie quisiera para sí mismo o alguno de los suyos, cuando la identificación con la voluntad del Padre, tan resaltada en el Evangelio y ratificada en la oración de Getsemaní $(14,36)$ ), alcanza su punto culminante y su máxima expresión.

Jesús muere como muere, no por puro conformismo, por meterse donde no debía, tampoco por un revés de la fortuna o por las razones culturales, políticas o sociales que se quieran, sino porque ha sido fiel hasta el final a su entrega de amor. Está donando su vida por nuestros pecados, en un acto de solidaridad y misericordia supremas con los hombres de todos 
los tiempos y de una forma insospechada. Él mismo tiene plena conciencia de ello y así lo expresa con solemnidad ante los discípulos durante la hora final que pasa con los suyos y que ya hemos comentado $(14,24)$.

Y muere sin Dios, porque en el momento mismo de su salir de este mundo no experimenta el consuelo divino. El vaciamiento total de su vida expropiada, el hundimiento sin límites de su proexistencia ha llegado a su punto culminante, sin posibilidad de marcha atrás. Baja hasta las formas más abismales de la desolación y el desamparo para vencer el mal, el pecado y la muerte. Nunca el Padre había estado más cerca de él que en ese terrible momento, pero Jesús no siente su presencia, cuando más la estaba necesitando, porque cargaba con el pecado de los hombres (Mt 26,28; cf. 1,21).

En la entrega de sí mismo en el madero de la Cruz, Jesús está depositando todo el pecado del mundo en el amor de Dios, que en su misericordia entrañable limpia de culpa a los pecadores. Pero en ese preciso momento Él, el justo por excelencia, el Hijo de Dios, a quien el centurión romano confiesa como tal $(15,39)$, siente en su naturaleza humana el abandono divino. ¡Gran misterio el modo como se llevó a cabo la salvación humana, que nos llena de admiración, consuelo, agradecimiento!

Desde el silencio el Padre se conmueve con el sufrimiento de su Hijo, como se conmueve con los que sufren injustamente; se compadece del desamparo de su Hijo, como se compadece de todos los desvalidos; consuela a la humanidad caída en medio del desconsuelo de su Hijo. La muerte de Jesús en la cruz nos está indicando que el Padre no abandona a ningún hombre, sea el que sea, no se olvida de su criatura predilecta, porque su Hijo, nuestro Hermano, nos ha salvado a todos en el madero de la cruz con la ofrenda de un amor desbordante de misericordia.

En palabras finales: La muerte de Jesús acontece ante la presencia del Padre vivo y bueno, que se complace en la reparación que su Hijo está realizando en la cruz, como fruto de su misericordia entrañable hacia los suyos y hacia la humanidad entera. En modo alguno aprueba el dolor de Jesús, pero lo sostiene, porque es fruto de un gran amor. Cuanto Jesús obra en su muerte, como en su vida entera, sólo puede ser entendido desde el amor misericordioso, de quien lo da todo sin esperar nada a cambio, aunque sus enemigos no lo puedan o no lo quieran percibir. ¡Un hecho más de la sublimación de su entrega!

El contraste, hasta la contradicción que supone la salida de Jesús de esta tierra, adquieren proporciones inusitadas: ¡Una muerte horrenda, fruto de una injusticia descomunal y un odio inmisericorde, como nunca antes se había visto, se transforma, en virtud del amor testimoniado por el Cru- 
cificado, en el principio supremo de la misericordia! No lo dudemos: el núcleo central de esa muerte, que constantemente celebramos los cristianos, está en la victoria de la misericordia sobre toda clase de desamores, en el triunfo del amor ante los mayores egoísmos.

\subsubsection{La complementación de la pasión lucana}

San Lucas, como San Marcos, concede también una importancia excepcional a la cruz y la sitúa en el centro mismo de la misericordia tanto del Padre como del Crucificado: La cruz no constituye el resultado de un fracaso, ni el desenlace de una existencia malograda, que ha dejado de tener sentido por muy diversas causas. Muchos menos la muerte violenta de Jesús significa la caída en la nada duradera y la bajada al abismo del absurdo. Más bien representa la entrega apasionada del Hijo por los hombres (Lc 9,22.44) y la misericordia sin límites del Padre bueno en beneficio de la humanidad caída. El Padre ha querido perdonar a los humanos en el abrazo de su Hijo crucificado, al darse a sus hermanos hasta las últimas consecuencias.

La cruz puede considerarse entonces como el icono perfecto del amor supremo, como la cima insuperable de la misericordia. ¡En ella resplandece la vida del auténtico amor! En ella aprendemos a amar lo que el Padre y el Hijo con tanta dedicación y predilección aman. Ojalá mirando al Crucificado, cada uno de nosotros aprenda a amar de esa manera: como el Padre y el Hijo nos aman, para llegar a la alegría y la felicidad que no pasan. Ojalá que seamos testigos de amor tan puro y directo ante nuestros semejantes, de modo especial ante los que necesitan nuestra ayuda y la piden a gritos. «Cristo me amó y se entregó por mí» $(\mathrm{Gal} 2,20)$ y se ha convertido para siempre en «sabiduría, justicia, santificación y salvación» (1 Cor 1,30). Que comportamos el sufrimiento de Cristo con nuestra capacidad de amar, compadecer y servir a los demás, convirtiéndonos en iconos del amor del Padre y del Hijo. Sólo en el amor puede brillar el esplendor de la salvación.

Se puede compartir el gozo y la alegría, también en la experiencia del desgarro crucificado, cuando se hace por amor y expresa la fidelidad al Crucificado. El dolor humano deja de ser misterio, para brillar como revelación, si se convierte en compasión y misericordia por los demás. Quien se encuentra arraigado en la fe y le mueve el amor, transforma la vida por completo, convirtiéndola incluso en bendición para los demás mediante el testimonio doliente. Porque nos amó hasta el extremo (Jn 13,1), Jesús no 
rehuyó nunca asumir el sufrimiento, aún el más descarnado y lacerante, venciendo así su aguijón con el amor. De esta manera nos enseñó el camino de la vida y nos mostró la senda segura para alcanzar la felicidad. En el dolor por los demás puede saltar la chispa del deber cumplido y la vida lograda.

El evangelista san Lucas ha presentado la pasión de Jesús y de un modo especial la cruz, como un pastor preocupado de la segunda generación cristiana, que desea que los lectores encuentren en ella la verdad, fuerza y sabiduría de Dios (cf. 1 Cor 1,24) y caigan en la cuenta que la salvación existe, tiene efectividad porque un bendito día apareció en Nazaret el profeta último y definitivo que con su existencia entregada hasta el final nos proporciona un ejemplo supremo de lo que consiste el verdadero amor, en el que brota la salvación para todos. Ese hombre bendito es el Hijo de Dios, el Mesías Salvador, el Hijo del hombre desde las dos laderas por obra del Espíritu: el mayor regalo del Padre de la misericordia a la humanidad y el mejor presente de la humanidad a Dios.

\subsection{Las apariciones del Resucitado (Jn 20,11-18. 19-23. 24-29)}

Ya no estamos ante el Jesús terreno, sino ante el Cristo Resucitado, objeto central de nuestra fe, sabiendo que entre ambos existe continuidad, nunca contraposición. Las apariciones sobrepasan la historia para introducirse en la experiencia relacionada con la vida religiosa del creyente. También las apariciones nos hablan de modo más o menos directo de la misericordia del Resucitado, que muestra la bondad del Padre.

\subsubsection{La aparición a María de Magdala (Jn 20,11-18)}

Hay dos tradiciones concurrentes en relación con la presentación del primer testigo de le Resurrección: Para Lc 24,14 y 1 Cor 15,5 fue Pedro, para Mc 16,9 y el pasaje que nos ocupa fue María de Magdala. Nos atenemos a la tradición joánica, que tiene muchas garantías de fiabilidad histórica, que aquí no podemos demostrar.

María reconoce a Jesús, al llamarla por su nombre, pronunciado como sólo Él podía hacerlo. A María, la desconsolada, se le abren los ojos de la fe y le inunda una inmensa alegría. Reconoce a su Señor y grita: « $R a b$ boni!». Se trata de una expresión festiva, más fuerte de «iRabbí!»= Maestro, empleado a menudo para dirigirse a Dios. Delante de ella se encuen- 
tra su Señor y Maestro, el que constituye el centro de su vida, el objeto de sus desvelos, la fuerza de su amor, quien se identifica con Dios. ¡Ahí está el Maestro bueno, misericordioso, que ha sido escarnecido y atormentado, pero que ha vuelto a la vida!

Sin pensarlo, llevada por su amor, la de Magdala se lanza hacia Jesús, arrojándose a los pies, para abrazárselos (Mt 28,9). María ha pasado toda una noche oscura. Ha compartido el dolor del Crucificado y ahora se siente transida por la luz y alegría del Resucitado. Abrazar sus pies supone reconocimiento y amor, sumisión y adoración. Su vida, pasada por la gracia de la Pascua, encuentra sentido pleno en el asimiento de su Señor y en el reconocimiento de su señorío sobre ella.

Pero Jesús no permite que le toque y le dice con ternura: «No me retengas, que todavía no he subido al Padre. Pero anda ve a mis hermanos y diles: "Subo al Padre mío y al Padre vuestro, al Dios mío y al Dios vuestro"”. Jesús ya no pertenece al mundo de las realidades físicas. Ha de subir al Padre, de quien procede y de cuyo hogar vino. Su presencia en este mundo ya no puede ser una presencia material. De ahora en adelante Jesús ocultará su corporeidad en la metahistoria, para dejar entrar en nuestras realidades físicas la fuerza del Espíritu (Jn 16,7ss). Él les hará comprender sus enseñanzas, la causa y los intereses, que representó y que en lo sucesivo tienen que representar ellos. Lo importante ahora es amar y mostrar la misericordia del Resucitado con la luminosidad que desprende la fe y con el testimonio de quien vive para amar.

Con una misericordia infinita el Resucitado sigue teniendo a los suyos como hermanos. Los llama de este modo. Por primera vez un evangelio pone en boca de Jesús la palabra hermanos, para dirigirse a sus discípulos. Y lo hace mediante la revelación de sus intenciones más íntimas a una mujer. Lo que va a venir después de la resurrección sólo puede entenderse como misericordia de Jesús con sus hermanos: Perdona su cobardía de abandonarlo a su suerte en el momento del prendimiento y de la pasión. Regenera sus egoísmos. Los hechos pasados han sido superados, aunque merece la pena retenerlos en la memoria para no volver a caer en ellos. La fraternidad se muestra más fuerte que nunca y, asistida con la fuerza del Espíritu, así perdurará en ellos y en el transcurso de la historia.

A través de María les comunica una gran noticia: el Resucitado sube a su Padre, que es también Padre de sus discípulos. De ahora en adelante estará junto a Él. Se realidad corporal transfigurada entra en la gloria definitiva, al lado del Dios vivo y verdadero. María recibe una entusiasmante misión, cargada de espera y esperanza. Se acredita como la gran mensajera 
de la Pascua. La tarea recomendada es grandiosa: devolver a los discípulos hermanados la fe en Jesús, suscitarles la esperanza que no pasa, haciéndoles caer en la cuenta que Jesús camina con ellos y está detrás de todos sus esfuerzos.

\subsubsection{La aparición a los Diez y a Tomás (Jn 20,19-25. 26-29.30s)}

La cronología divide perfectamente las dos partes del relato: la primera (versículos 19-25) acontece el mismo día de la Pascua, «al anochecer». La segunda (v. 26-29) sucede «ocho días» después, que en lenguaje litúrgico suele llamarse dominica in albis. Ambas partes contienen sendas apariciones del Resucitado, en las que brilla su mensaje de misericordia.

1. Cuando está cayendo el domingo de la Pascua, Jesús se aparece de improviso a los discípulos, que están encerrados en una casa no identificada, posiblemente en la que celebraron la última cena. Se encuentran amedrentados y, por eso, se aíslan por miedo a judíos, que les tienen marcados en su punto de mira. Cierran bien las puertas para mayor seguridad. Aún conservan muy presente el ajusticiamiento de Jesús en la cruz. Ese mismo día María de Magdala les ha anunciado el haber visto al Señor (Jn 20,18), pero ellos no acaban de creer tan buena noticia, que puede cambiar por completo su vida.

Ahora el mismo Resucitado, con una misericordia sin límites, se aparece de improviso a los suyos, trayéndoles la paz que sólo puede provenir de la Trinidad misericordiosa. Esa paz que pacifica con Dios, con uno mismo, con los otros hombres y con la creación entera. Esa paz, capaz de transformar los corazones y comunicar alegría, tranquilidad y esperanza a los entristecidos, inquietos y desesperanzados. Los que se encontraban en un callejón sin salida, empiezan a contemplar un camino abierto de luz. La tristeza da paso al gozo contenido. Ha tenido pleno sentido seguir a su Maestro, que ahora, vencida la muerte, goza de la vida definitiva de Dios.

El Señor de vivos les envía a la misión, anclados en Dios: «Como el Padre me ha enviado, así os envío yo. Y dicho esto, sopló sobre ellos y les dijo: "Recibid el Espíritu Santo; a quienes les perdonéis los pecados, les queda perdonados; a quienes se los retengáis, les quedan retenidos”».

La obra proyectada por el Padre en sus designios amorosos para con los hombres e iniciada por Jesús durante su actividad terrena, está llamada a ser continuada así por los discípulos con la asistencia imprescindible del Espíritu. Se trata de una obra apasionante a favor de la salvación de la hu- 
manidad que continuará hasta el final de la historia. No tiene ocaso, de modo que, de ahora en adelante, se va a proseguir por medio de los que creen en Jesús y están dispuestos a aceptar la tarea confiada con la ilusión propia de los que están convencidos de hacer algo grande para el presente y futuro del ser humano. En el centro de esa tarea se alza el Evangelio de la misericordia del Padre y del Resucitado, muerto por nuestros pecados y levantado del reino de la muerte para nuestra salvación.

Las apariciones del Resucitado acaban invariablemente con el encargo de la misión. Pero aquí esa misión no se considera tan sólo como tarea humana, se retrotrae a su raíz más profunda, la misión trinitaria, modelo permanente de toda misión eclesial. El envío del Padre a Jesús por la acción del Espíritu se alarga en el envío del Resucitado, el plenipotenciario divino, a los suyos. Los discípulos se integran así en la vida misma de la Trinidad y se hacen partícipes de sus planes salvadores, equipados con su misericordia entrañable. ¿Podían tan siquiera soñar en realizar empresas mayores, cuando ahora conocen sapiencialmente que se encuentran acompañados y sostenidos por el mismo Dios de los cielos?

Dos realidades comportan la misión encomendada a los discípulos: la recepción del Espíritu y la remisión de los pecados. El encargo confiado sólo resulta realizable con la asistencia imprescindible del Espíritu, que se acredita como el otro Jesús, que nos lleva a la realidad plena y nos convierte en testigos convincentes del Evangelio para salvación de la humanidad.

Lo más sagrado del cometido de los discípulos consiste en perdonar los pecados en nombre de Dios y abrir a los hombres a una vida nueva de paz interior y equilibrado compromiso exterior. Únicamente pacificado consigo mismo y con los demás el hombre, sostenido por el amor divino, el creyente puede lograr su existencia en el devenir diario de trato con los otros. Existe una relación íntima e indestructible entre la recepción del Espíritu, la remisión de los pecados y el fruto de la misericordia.

2. Al domingo siguiente Jesús se vuelve aparecer. En este momento se encuentra entre ellos Tomás, uno del grupo de los Doce, que no estaba en la casa, cuando Jesús se les apareció. No ha creído lo que sus compañeros le han comunicado de haber visto al Señor. Ahora el Resucitado se vuelve hacia él, de modo que la escena se centra en el diálogo mantenido con el discípulo incrédulo. Las palabras intercambiadas entre ambos en el encuentro son pocas, pero tienen gran densidad y notable significación para los creyentes de cualquier época.

El diálogo adquiere su momento culminante con la confesión de fe del descreído Tomás: «!Señor mío y Dios míoj». Contiene la exclamación sin- 
cera y hasta gozosa de quien, vencido por la fuerza de los hechos, siente su indignidad ante Dios y su Mesías. Expresa, al mismo tiempo, el reconocimiento humilde de quien está dispuesto a cambiar el rumbo de su actuación con fuerzas renovadas, guiado por el que se acredita como el Señor de la vida. Muestra, también, la disposición de querer proseguir su causa hasta las últimas consecuencias.

Las palabras finales de Jesús: «¿Porque me has visto has creído? Dichosos los que crean sin haber visto», pueden entenderse como una seria advertencia a los cristianos de todos los tiempos, para que creamos en la resurrección de Jesús, fiados en el testimonio apostólico y en la credibilidad de la Iglesia. Quien cree sin ver en el interior de la comunidad es objeto de una bienaventuranza del Resucitado. Conformemos nuestra vida de tal modo que experimentemos cómo el Resucitado nos acompaña siempre con la verdad de su presencia invisible y la fuerza de su actuación por medio de los dones del Espíritu.

3. El pequeño texto final ofrece una alta significación: el evangelista no se dirige a los judíos ni a los gentiles, sino a los cristianos que leen su obra, para mostrarles que Jesús de Nazaret, y nadie más, es el Mesías y el Hijo de Dios y que la salvación sólo se da por la proclamación de la fe en su mesianidad y en su filiación divina. Únicamente confesando al Resucitado como Hijo de Dios y también como Mesías, el creyente puede expresar su fe, y mostrar su confianza en la bondad infinita del Padre, mucho más en el año que se celebra el Jubileo de la Misericordia.

\section{NUNCA LA MISERICORDIA DE JESÚS SE HABÍA MANIFESTADO CON TANTA FUERZA DE CONVICCIÓN Y TANTA VERDAD DE AMOR, COMO EN LA INSTITUCIÓN DE LA EUCARISTÍA Y EN LA ENTREGA DE SU VIDA POR NOSOTROS EN LA CRUZ. EN ELLAS PRENDE LA GLORIA DE LA RESURRECCIÓN.}

\section{La Pascua de Jesús nos habla de la misericordia de la Trinidad}

El acontecimiento de la resurrección como tal adquiere para los creyentes de todos los tiempos una significación máxima en la revelación de la misericordia de la Trinidad, manifestada de forma plena en el Resucitado. 
La Pascua del Resucitado crucificado habla de la Trinidad en su arrebato de amor y salvación para con los hombres. La Trinidad es Unidad interrelacionada por la Misericordia: los Tres son Uno y el Uno son Tres en el Amor: Padre en el origen, Hijo en la encarnación y Espíritu Santo en el lazo de unión. En la Trinidad Santa, revelada en la Pascua, culmina la misericordia divina en la historia humana. De hecho constituye el signo más eficaz del obrar del Padre, del Hijo y del Espíritu Santo en la humanidad caída y regenerada.

Efectivamente, la Trinidad ha actuado, como nunca antes lo había hecho, en esa Pascua bendita del Hijo humanado, que desgastó su existencia terrena, murió y resucitó por nosotros. Resulta una exigencia ineludible de nuestra fe y esperanza relacionar íntimamente estas tres realidades con mayúsculas: Pascua, Trinidad y Misericordia. El Resucitado se hace visible en cada momento y plenifica de forma definitiva la misericordia trinitaria.

En el acontecimiento de su resurrección el Hijo humanado experimenta en sí mismo la misericordia del Padre a través de la acción del Espíritu, haciendo visible, palpable y experimentable esa misericordia también en los hombres, sus hermanos. Por medio del Resucitado la Trinidad Santa nos ha regalado como gracia esa misericordia que es anterior a cada uno de nosotros: a nuestra misma existencia, a nuestras propias posibilidades concretas, a nuestra capacidad de merecer.

La misericordia, que nace de la muerte y resurrección de Cristo construye el verdadero humanismo, al Hombre Nuevo, destinado a la vida, la solidaridad y la felicidad. El amor generoso y misericordioso siempre puede más: vence al pecado, el mal y la muerte y nos sitúa en la órbita de la salvación. He aquí la gran noticia: Estamos salvados para el amor, la regeneración y el perdón, por la bondad, la ternura y misericordia de la Trinidad Santa. Hablamos ahora del amor misericordioso del Padre, después de la salvación y vida del Hijo y, por último, de la gracia y la verdad del Espíritu Santo, que tanto tienen que ver con la plasmación de la misericordia en nuestras vidas.

\subsection{Del amor misericordioso del Padre (JN 3,16-18)}

Una de las reflexiones más conmovedoras del Cuarto Evangelio la encontramos en el diálogo con Nicodemo y encaja perfectamente en esta reflexión. En un momento de la conversación Jesús, que nos ha dado a conocer los secretos más recónditos del Padre, nos hace esta sorprendente 
revelación: «Porque tanto amó Dios al mundo, que entregó a su Unigénito, para que todo el que cree en él no perezca, sino que tenga vida eterna. Porque Dios no envió su Hijo al mundo para juzgar al mundo, sino para que el mundo se salve por él» $(3,16 \mathrm{~s})$.

Estamos ante una reflexión definitiva, que ha quedado grabada en la memoria y en el corazón en los creyentes de todos los tiempos. Tiene por objeto mostrar el increíble amor del Padre al «mundo», es decir, al mundo de los hombres, que se había separado de los designios de Dios y caminaba hacia el abismo, habiendo perdido la vida genuina y pudiéndose atraer la «ira divina» $(3,36)$. El amor reconciliador de Dios mediante la entrega de su Hijo está en el centro mismo de la misericordia, de modo que ha cambiado por completo el destino del mundo. Es el amor dispensador de vida auténtica, que transforma radicalmente la realidad humana y se vuelve agradecimiento.

El evangelista quiere que pongamos nuestra mirada en el Padre y reflexionemos sobre lo mucho que nos ha amado con infinita misericordia a cada hombre concreto, a la humanidad entera. Ese amor inmenso se ha mostrado en el hecho fehaciente de que nos ha entregado a su Hijo Jesús, que podemos considerarlo como la Misericordia divina hecha carne, condición humana. Y ha venido a este mundo no para juzgarlo o condenarlo, sino para llevarlo de vida a través de su aceptación por medio de la fe. Rechazar esa fe significa tanto como ponerse en el camino de la perdición: «El que cree en él no será juzgado; el que no cree ya está juzgado, porque no ha creído en el nombre del Unigénito del Padre» $(3,18)$.

En Jesús de Nazaret se ha manifestado en su forma definitiva la cercanía de la Trinidad a los hombres. El amor misericordioso del Padre para con nosotros ha encontrado su punto culminante, imposible de superar, en la persona, vida y obra de Jesús, Amor de gracia, entregado a la humanidad caída. En pocas palabras: Podemos definir a Jesús como la Misericordia del Padre, hecha realidad humana, convertida en amor entrañable, venido a este mundo para consolidar la vida de verdad. Su rostro, su palabra y su actuación transparentan el obrar divino, de modo que aceptar la misericordia de Jesús funda la entrada en la vida eterna. En la búsqueda del Dios vivo y verdadero, el Resucitado nos revela que su rostro entrañable es el del Padre de la Misericordia Infinita, que podemos contemplar con agradecimiento y una alegría inmensa. 


\subsection{De la salvación y vida del Hijo (Jn 5,21-26)}

La trayectoria humana de Jesús consiste en la historia de un amor cumplido. Al mismo tiempo ofrece la garantía de ser un amor verdadero, que no busca nada a cambio y lo entrega todo. Merece la pena leer el capítulo 17 del Cuarto Evangelio, la llamada oración sacerdotal, para comprobar la conmoción y el drama de amor fraterno, que Jesús el Hijo presenta ante el Padre. Las fuentes del amor están en ese Padre bueno y el sujeto predilecto de su amor es Jesús, donde encuentra su principio y fundamento. De ese amor del Padre procede al amor del Hijo humanado a sus íntimos, a sus discípulos, dándose así un círculo amoroso permanente: "Como el Padre me ha amado, así os he amado yo; permaneced en mi amor» (Jn 15,9). Permanecer en el amor de Jesús significa tanto como experimentar su misericordia salvadora y hacerla visible ante los demás mediante el testimonio correspondido.

Jesús no tiene otro baremo en la práctica de su amor, que el que se deduce de la actuación del Padre, al que se siente íntimamente unido. Con la fuerza desbordante del Espíritu vive amando, no pudiéndose concebir en su persona otra forma de existir más que amando, comunicando y entregando amor. ¡Vivir sin amar sería para su Bendita Persona tanto como negar lo más sagrado de sí mismo, porque el amor conforma su misma esencia! De ese amor que es vida en plenitud, depende por completo el de Jesús y también el de sus discípulos: el nuestro es un amor sostenido por el $\mathrm{Pa}$ dre en su misericordia entrañable.

Ese amor cumplido de Jesús, testimoniado de muy diversas formas a lo largo de su andadura terrena, ha encontrado su culminación al pasar Jesús de la muerte a la resurrección. Nos ha mostrado algo decisivo: que el amor supera el dolor y es más fuerte que la muerte, de modo que el Resucitado nos ha abierto a la vida divina con todas las garantías de verdad y eficacia, como se abrió la suya. Su muerte engendra la Vida, produce la Salvación con mayúsculas. Y de esa Vida y Salvación bebemos los creyentes.

Escuchemos al mismo Cristo Hijo y dejemos que sus palabras penetren en nuestro corazón: «Lo mismo que el Padre resucita a los muertos y les da vida, así también el Hijo da vida a los que quiere... En verdad, en verdad os digo: Quien escuch a mi palabra y cree al que me envió posee la vida eterna y no incurre en juicio, sino que ha pasado ya de la muerte a la vida. En verdad, en verdad os digo: llega la hora, y ya está aquí, en que los muertos oirán la voz del Hijo de Dios, y los que hayan oído vivirán. Porque igual que 
el Padre tiene vida en sí mismo, así ha dado también al Hijo tener vida en sí mismo» (Jn 5,21.24-26).

¡Consoladoras son estas palabras solemnes tan cargadas de promesas! Creer en el Padre y escuchar la voz del Hijo, enviado a los hombres, nos proporciona la vida, que proviene de lo alto. En realidad es el amor al Padre y al Hijo lo que hace posible la verdadera vida a través de la aceptación gozosa de la fe. Llevados por la misericordia del Padre, lo que importa es amar y permanecer en el amor testimoniado y verificado por el Hijo humanado, que nos hermana a los hombres y nos introduce en una dimensión insospechada. Nos recuerda que merece la pena acoger la realidad gozosa de la Pascua, que hace de cada uno de nosotros hombres nuevos, renovados por dentro y con una actuación por fuera propia del que ha visto la gloria del Hijo humanado y la sigue.

El amor misericordioso del Resucitado viene a nuestras vidas cargado de matices, conforme se verifica en la existencia diaria. Entre ellos se encuentran la acogida y la cercanía, el perdón y la extirpación de la culpa, la compasión y la entrañabilidad, la ternura y el cariño. Conviene conservar todos esos rasgos, para que los discípulos sepamos permanecer en ese amor resucitado. Sin esa real permanencia será imposible un testimonio convincente hacia los demás y vivir cada día como auténticas personas regeneradas en Cristo Jesús.

\subsection{De la gracia y verdad del Espíritu Santo (Jn 14,16s.26;} $16,12-15)$

Cuanto está escrito aquí, sólo resulta posible hacerlo verdad y vida, experimentarlo interiormente y testimoniarlo exteriormente mediante la actuación del Espíritu en cada uno de nosotros. El Espíritu del Padre y del Hijo, que es puro Amor y Don, posibilita que acojamos la misericordia del Padre en nuestro corazón, que hagamos nuestra la salvación y vida del Hijo, conforme a lo expresado por Jesús en los discursos del adiós del Evangelio de Juan.

«Y yo pediré al Padre que os dé otro Paráclito, que esté siempre con vosotros, el Espíritu de la verdad. El mundo no puede recibirlo, porque no lo ve ni lo conoce; vosotros, en cambio lo conocéis, porque mora con vosotros y está con vosotros» (Jn 14,16s). Ese Paráclito, ese otro Jesús, para los tiempos en que ya no nos acompaña con su vida terrena, es el Espíritu de la verdad, apartado por completo de la falsedad mundo. Cuando lo acoge- 
mos y le damos cabida en nuestro interior, nos inhabita hasta el punto que está más dentro de nosotros que lo estamos nosotros mismos. Y en la hondura de nuestro ser nos dice quien es el Padre para nosotros y nos facilita experimentar cómo nos inunda de amor con su compasión y misericordia.

«Muchas cosas me quedan por deciros, pero no podéis cargar con ellas por ahora; cuando venga él, el Espíritu de la verdad, os guiará hasta la verdad plena. Pues no hablará por cuenta propia, sino que hablará de lo que oye y os comunicará lo que está por venir. Él me glorificará, porque recibirá de lo mío y os lo anunciará. Todo lo que tiene el Padre es mío. Por eso os he dicho que recibirá y tomará de lo mío y os lo anunciará»(Jn 16,12-15).

La misericordia es lo más propio del amor de Cristo y de esa misericordia entrañable nos hablará el Espíritu de tú a tú, de amor a amor. Podrá alcanzar lo más íntimo de nuestras vidas y volverse para cada uno de nosotros en luz, verdad y amor con todas las consecuencias. Que mediante la acción transformadora del Espíritu acojamos la misericordia del Padre y la salvación de su Hijo humanado. Testimoniemos esta misericordia ante nuestros semejantes y alcancemos una vida dichosa. ¡Que brille hasta el final la misericordia de la Trinidad en cada uno de nosotros y que la sepamos testimoniar ante el mundo!

Uno de los más famosos poetas malditos de mediados del siglo XIX, conde de Lautréamont (1846-1870), considerado como uno de los nombres primeros de la poesía moderna y que murió de tuberculosis en París con tan solo veinticuatro años de edad, nos ha dejado este tremendo testimonio: "Mis años no son numerosos y, sin embargo, siento ya que la bondad es solo un ensamblaje de sílabas sonoras; no la he encontrado en ninguna parte» (Isidore Lucien DuCASSE, Los cantos de Maldoror [Madrid 2016; editorial Valdemar] II canto).

¡Qué pena que este atormentado joven, que a lo largo de gran parte de su atormentada existencia aborreció a Dios y a los hombres, no tuviera un encuentro con Cristo y hubiera podido mantener una verdadera relación con Jesucristo, mediada por el Espíritu Santo! ¡Si se le hubiera manifestado en Cristo la realidad luminosa y potente de la misericordia divina, así como su impacto estético, seguro que hubiera elegido otro camino! ¡Habría gustado lo que significa en verdad la bondad y lo que tiene de bueno y bello la misericordia y esta experiencia sin duda le habría transformado por dentro y por fuera!

Desde luego no habría pronunciado una frase tan estremecedora y su corta vida habría tomado otro rumbo, aunque parece ser que muy al final percibió otro modo de existir mucho más positivo: «He renegado de mi pa- 
sado. Ya no canto más que a la esperanza». En este lado de la esperanza se alza la misericordia entrañable divina, la que puede ser que sintiera en la hora de la muerte. ¡A la esperanza cierta y alegre nos abre el Espíritu; una esperanza que tiene como contenido y centro la muerte y resurrección de Jesús, la causa de la misericordia; esa misericordia que aun el hombre más desesperado puede experimentar, llegado el momento!

\section{LA VIDA PUEDE SER BENDITA Y LA CONFORMAMOS CADA UNO DE NOSOTROS, CON LA MISERICORDIA ENTRAÑABLE DE LA TRINIDAD SANTA, CUANDO NOS DECIDIMOS POR LA FILIACIÓN Y LA FRATERNIDAD, CONSEGUIDA POR EL RESUCITADO CRUCIFICADO.}

